University of Nebraska - Lincoln

DigitalCommons@University of Nebraska - Lincoln

2008

\title{
An Exploration of Diversity among the Ostertagiinae (Nematoda: Trichostrongyloidea) in Ungulates from Sub-Saharan Africa with a Proposal for a New Genus
}

\author{
Eric P. Hoberg \\ National Parasite Collection, Agricultural Research Service, United States Department of Agriculture, \\ ehoberg@ggpl.arsusda.gov \\ Arthur Abrams \\ Animal Parasitic Diseases Laboratory, Agricultural Research Service, United States Department of \\ Agriculture, art.abrams@ars.usda.gov \\ Vanessa O. Ezenwa \\ University of Montana, Missoula, vanessa.ezenwa@umontana.edu
}

Follow this and additional works at: https://digitalcommons.unl.edu/parasitologyfacpubs

Part of the Parasitology Commons

Hoberg, Eric P.; Abrams, Arthur; and Ezenwa, Vanessa O., "An Exploration of Diversity among the Ostertagiinae (Nematoda: Trichostrongyloidea) in Ungulates from Sub-Saharan Africa with a Proposal for a New Genus" (2008). Faculty Publications from the Harold W. Manter Laboratory of Parasitology. 642. https://digitalcommons.unl.edu/parasitologyfacpubs/642

This Article is brought to you for free and open access by the Parasitology, Harold W. Manter Laboratory of at DigitalCommons@University of Nebraska - Lincoln. It has been accepted for inclusion in Faculty Publications from the Harold W. Manter Laboratory of Parasitology by an authorized administrator of DigitalCommons@University of Nebraska - Lincoln. 


\title{
AN EXPLORATION OF DIVERSITY AMONG THE OSTERTAGIINAE (NEMATODA: TRICHOSTRONGYLOIDEA) IN UNGULATES FROM SUB-SAHARAN AFRICA WITH A PROPOSAL FOR A NEW GENUS
}

\author{
Eric P. Hoberg, Arthur Abrams, and Vanessa O. Ezenwa* \\ U.S. National Parasite Collection and Animal Parasitic Diseases Laboratory, Agricultural Research Service, United States Department of \\ Agriculture, BARC East 1180, 10300 Baltimore Avenue, Beltsville, Maryland 20705. e-mail: eric.hoberg@ars.usda.gov
}

\begin{abstract}
Abomasal nematodes (Ostertagiine: Trichostrongyloidea) representing a previously unrecognized genus and species are reported in African buffalo (Syncerus caffer caffer) from Kenya, Uganda, and South Africa. Africanastrongylus buceros gen. nov. et sp. nov. is characterized by a symmetrical tapering synlophe in the cervical region and a maximum of 60 ridges in males and females. Bursal structure is 2-2-1, with subequal Rays 4/5, massive Rays 8, and Rays 9/10, and a massive dorsal lobe that is reduced in length, laterally and dorsally inflated, and positioned ventral to externodorsal rays. Spicules are tripartite, and the gubernaculum is broadly alate in the anterior. A proconus is present. Among ostertagiines with a 2-2-1 bursa (Cervicaprastrongylus, Hyostrongylus, Mazamastrongylus, Sarwaria, Spiculopteragia, and Teladorsagia) specimens of Africanastrongylus are differentiated from respective genera based on the structure of the cervical synlophe, patterns of dorsal, externodorsal, lateral, and ventral rays, and configuration of the genital cone, gubernaculum, and spicules. Among 13 genera of the Ostertagiinae in the global fauna, 3 are entirely limited in distribution to Africa, including Africanastrongylus, Longistrongylus, and Pseudomarshallagia. Another 5 genera including Cervicaprastrongylus, Hyostrongylus, Marshallagia, Ostertagia, and Teladorsagia are represented as mosaics, with diversity centered in Eurasia or the Holarctic. Genera not represented in the African fauna include Camelostrongylus among Caprinae and some Antelopinae from Eurasia, Mazamastrongylus and Spiculopteragia in Cervidae from the Holarctic and Eurasia, respectively, Orloffia in Cervidae and Bovidae from the Holarctic, and Sarwaria among Tragulidae and Bovinae in southern Asia. The diverse nature of the ostertagiine fauna, with a disproportionate number of endemic genera relative to other regions of the northern hemisphere, may reflect the timing of episodic expansion events for artiodactyls into Africa from Eurasia during the Tertiary and Quaternary.
\end{abstract}

Ostertagiine nematodes represent a monophyletic group within the Trichostrongyloidea with a primary geographic distribution centered in Eurasia and the Holarctic Region (Durette-Desset, 1985; Lichtenfels and Hoberg, 1993; Hoberg and Lichtenfels 1994; Durette-Desset et al., 1999). Across Africa, diversity for species of Ostertagiinae, primarily abomasal nematodes among artiodactyls, appears relatively limited. Extensive survey and inventory over the past century among Bovinae, Antelopinae, and other pecoran artiodactyls have revealed relatively few endemic species, except for those in the genus Longistrongylus Le Roux 1931, and among the otherwise geographically widespread Ostertagia Ransom, 1907 (e.g., Mönnig, 1932; Round, 1968; Gibbons, 1977; Gibbons and Khalil, 1980; Boomker and Durette-Desset, 2003).

Among the diverse ungulate fauna characteristic of sub-Saharan Africa, there are relatively few reports of ostertagiine or other abomasal parasites in African buffalo (Syncerus caffer (Sparrman)). These have been limited to Longistrongylus meyeri Le Roux, 1931; species of Ostertagia Ransom, 1907 from Uganda (Dinnik et al., 1963; Bwangamoi, 1968); Ashworthius lerouxi Diaouré, 1964 from Congo (Diaouré, 1964), Haemonchus bedfordi Le Roux, 1929 from Uganda (Dinnik et al., 1963) and South Africa (Le Roux, 1929; Ortlepp, 1961); Haemonchus contortus (Rudolphi, 1803) from Kenya and South Africa (Curson, 1928; Ezenwa, 2003); and Haemonchus placei Place, 1893 from Kenya (Ezenwa, 2003).

Surveys in the late 1960s and more recent collections of wild African buffalo, or Cape buffalo (Syncerus caffer caffer (Sparrman)) from Uganda, Kenya, and South Africa have now revealed a previously unrecognized genus and undescribed species of ostertagiine nematode. We provide a generic diagnosis and the first description of these ostertagiines. Concurrently, we

Received 16 April 2007; revised 14 July 2007; accepted 17 July 2007 *Division of Biological Sciences, University of Montana, Missoula, Montana 59812. explore (1) the limits and criteria for genera within the Ostertagiinae (see also Hoberg and Abrams, 2007), and (2) aspects of the structure of the ostertagiine fauna among African ungulates. Faunal discovery, inventory, and characterization of biodiversity for complex faunas are cornerstones necessary for understanding, documenting, and predicting biotic responses to ecological perturbation under an expanding regime of global climate change (Brooks and Hoberg, 2000, 2006; Hoberg and Brooks, 2008).

\section{MATERIALS AND METHODS}

\section{Specimens examined}

Abomasal nematodes in African buffalo or Cape buffalo, S. caffer caffer (Sparrman), were collected from widely separated localities in Africa (Table I). Specimens in 2 hosts from localities in Uganda (Field 11 at Anaka Village, West Acholi District and 33 at Queen Elizabeth National Park, Toro District) were collected by J. Bindernagle during 1964-1967 and originally studied at the U.S. National Parasite Collection in the late 1960 s by W. W. Becklund and M. L. Walker, who noted the distinctive morphology of these nematodes. Additional specimens were collected by 1 of us (V.E.), from 1 adult female host (Field BN1200 on 2 February 2000) at the Mpala Ranch, Laikipia, Kenya and 2 subadult females (Field B13 on 29 May 2006; C72 on 30 May 2006) at Hluhluwe-iMfolozi Park, KwaZulu-Natal, South Africa. All specimens were archived permanently at the U.S. National Parasite Collection and stored in a mixture of $70 \%$ ethanol, 5\% glycerin, and 3\% formalin.

\section{Other specimens examined}

Specimens and sources of other species of ostertagiine nematodes used in comparative morphological studies are listed (Table I).

\section{Microscopy}

Nematodes were prepared as temporary whole mounts cleared in phenol-alcohol (80 parts melted phenol crystals and 20 parts absolute ethanol) and examined with interference contrast microscopy. The synlophe was studied in whole mounts with particular attention to the pattern of ridge systems in the cervical zone and their extent posteriad in males and females consistent with prior studies among the ostertagiines (Lich- 


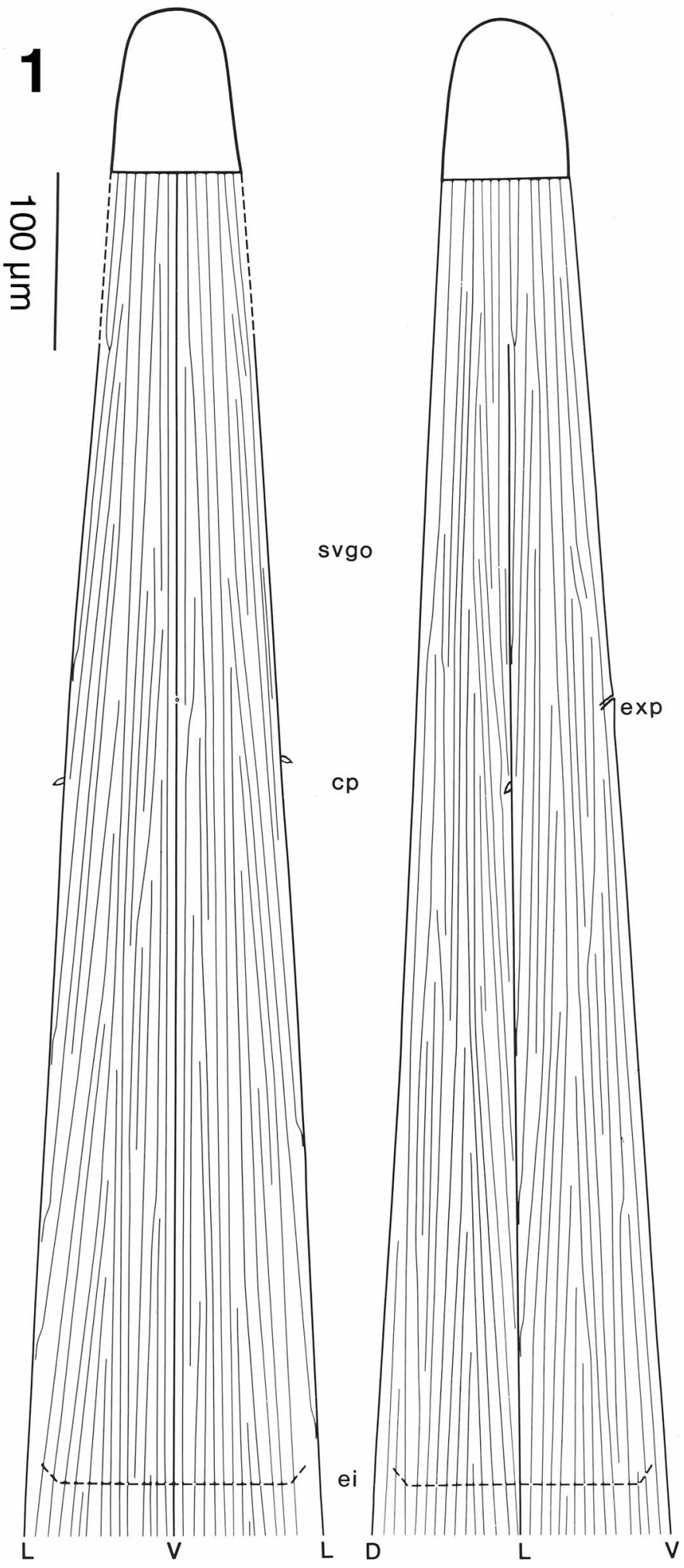

FIGURE 1. Africanastrongylus buceros gen. nov. et sp. nov., showing line drawings of the cervical synlophe in ventral and right lateral views of a female paratype (USNPC 66322). The excretory pore (exp) is on the ventralmost ridge consistent with a Type-B ventral pattern. Laterally the synlophe describes a Type-1 pattern; note relative positions for the subventral gland orifices (svgo), cervical papillae (cp), and esophagealintestinal junction (ei). Orientation is indicated by $\mathrm{v}=$ ventral, $\mathrm{d}=$ dorsal, and $1=$ lateral. tenfels et al., 1988). Thick transverse sections were hand cut with a cataract knife and mounted in glycerin jelly; methods were based on those developed by Durette-Desset (1983). Sections were used to count the number of ridges in a single male and female at the esophagealintestinal junction (EIJ), 1/4, midbody, and 3/4 of total body length as determined from the anterior. Sectioning was completed for only 2 specimens due to the limited number of worms that had been collected. Additional counts of ridges were based on reconstructions from whole mounted specimens.

The male specimens were evaluated on the basis of the copulatory bursa, spicules, and genital cone. Bursal ray patterns were determined and described under the system of Durette-Desset and Chabaud (1981) and Durette-Desset (1983). Papillae of the genital cone and rays of the bursa followed the numbering system of Chabaud et al. (1970). The structure of the ovijectors was evaluated in the context of recent definitions and descriptions among related nematodes (Lichtenfels et al., 2003). All measurements are given in micrometers, unless specified otherwise. In the description and tables the sample size $(n=)$ is followed by the range and mean $\pm 1 \mathrm{SD}$ in parentheses.

\section{Host nomenclature}

Taxonomy for hosts follows Wilson and Reeder (1993) in all of the text and tables. Host listings have been modified from those reported in the original literature to reflect current usage and understanding of ungulate taxonomy.

\section{RESULTS}

Field collections for survey of helminth diversity in ungulates from eastern and southern Africa revealed the occurrence of abomasal nematodes. Wild Cape buffalo from the West Acholi District of Uganda and the Queen Elizabeth National Park, Toro District, Uganda, Laikipia, Kenya and the Hluhluwe-iMfolozi Park in KwaZulu-Natal, South Africa were naturally infected with a previously undiagnosed genus and undescribed species of ostertagiine with a $2-2-1$ bursal form.

\section{DESCRIPTION}

\section{Africanastrongylus gen. nov.}

Diagnosis: Trichostrongylidae. Small uncoiled nematodes with welldeveloped bilateral tapering synlophe, miniscule thornlike cervical papillae and prominent esophageal-intestinal valve in males and females. Males monomorphic. Bursal structure 2-2 -1 , symmetrical, membrane lacking discrete fields of bosses. Rays $2 / 3$ curved, divergent through midlength, convergent distally; Rays 4/5 parallel throughout length, highly divergent distally at tips; relatively narrow, subequal with Rays $4 \leq$ Rays 5. Accessory bursal membrane simple, bilobed, containing filamentous papillae "7." Rays 8, massive curved mediad. Dorsal lobe massive, reduced in length, laterally and dorsally inflated, positioned ventral to externodorsal rays. Dorsal ray, or Rays 9/10, massive with stout base proximally, positioned ventral relative to Rays 8 . Genital cone with weakly developed proconus; paired " 0 " papillae miniscule, positioned posterior to proconus on ventral aspect of cloaca. Cloaca with telamon and cuticularized support structures at orifice. Spicules alate, trifurcate, subequal. Gubernaculum present, proximally alate. Females amphidelphic with transverse vulva in posterior quarter lacking cuticular fans or inflations.

\section{Taxonomic summary}

Type species: Africanastrongylus buceros gen. nov. et sp. nov. Host: African buffalo, S. caffer (Sparrman).

\section{Africanastrongylus buceros sp. nov. (Figs. 1-42)}

Diagnosis: Trichostrongylidae, uncoiled. Cuticle with well-developed synlophe, lacking gradient, with perpendicular orientation; maximum number of ridges, 60, in anterior quarter. Cervical papillae (CP) miniscule, triangular, thornlike near level of nerve ring, subventral gland 
TABLE I. Specimens of Africanastrongylus buceros gen. nov. et sp. nov. and other ostertagiines examined.

\begin{tabular}{|c|c|c|c|c|c|c|}
\hline USNPC $99545 \S$ & 11 & Africanastrongylus buceros & Syncerus caffer & Uganda & 1 & - \\
\hline USNPC $99546 \S$ & 33 & A. buceros & S. caffer & Uganda & - & 1 \\
\hline USNPC $99551 \|$ & 33 & A. buceros & S. caffer & Uganda & 5 & 2 \\
\hline USNPC 66322.02\| & 11 & A. buceros & S. caffer & Uganda & 7 & 7 \\
\hline USNPC 99547\| & BN1-200 & A. buceros & S. caffer & Kenya & - & 5 \\
\hline
\end{tabular}

Other species of ostertagiines

\begin{tabular}{|c|c|c|c|c|c|c|}
\hline OHC $2366 \S \|$ & - & Teladorsagia hamata & Antidorcas marsupialis & South Africa & Not available & \\
\hline UP T-2053\# & - & T. hamata & A. marsupialis & South Africa & 1 & - \\
\hline \multirow[t]{2}{*}{ BNH 1998.10.26.22-26\| } & - & Ostertagia kenyensis & Gazella granti & Kenya & 2 & 2 \\
\hline & & & Madoqua kirkii & Kenya & & \\
\hline USNPC 81213 & - & Longistrongylus curvispiculum $\mathbb{I}$ & Ovis aries & Texas, USA & 2 & - \\
\hline USNPC 77484 & - & Longistrongylus sabie** & Aepyceros melampus & South Africa & 4 & - \\
\hline USNPC 66325 & - & 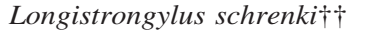 & Ourebia ourebi & Uganda & 4 & - \\
\hline USNPC 66323 & - & L. schrenki & Kobus kob & Uganda & 2 & - \\
\hline
\end{tabular}

* Collection numbers from the U.S. National Parasite Collection (USNPC), Onderstepoort Helminthological Collection (OHC), the Natural History Museum, London

(BNH), and University of Pretoria (UP).

$\dagger$ Field number at time of original collection.

$\downarrow$ Number of male and female specimens examined.

$\S$ Holotype male and allotype female.

|| Paratypes.

\# Syntype, from original collection by H. O. Mönnig, on 1 August 1931 at Houtkraal Farm, Karoo, Cape Province, derived from host following transport to Pretoria Zoo (Mönnig, 1932).

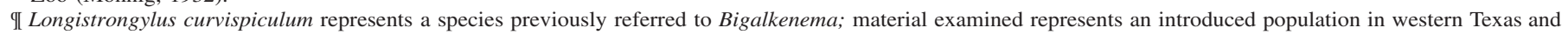
was from an experimental infection in domestic sheep based on larvae recovered from Oryx biesa (data from Craig, 1993).

** Longistrongylus sabie represents a species previously referred to Bigalkenema.

$\dagger \dagger$ Longistrongylus schrenki represents the species previously referred to Kobusinema.

orifices (SVGO), and situated slightly posterior to level of excretory pore (EXP). Cuticular ornamentation at level of EXP lacking. Esophagus with prominent valve at esophageal-intestinal junction (EIJ). Males and females monomorphic.

Bilaterally symmetrical synlophe similar in males and females. Cervical zone $(\mathrm{n}=3)$ with $29-30$ ridges extending to level of cephalic expansion increasing to $(\mathrm{n}=5) 50-58$ ridges at the EIJ. Laterally, synlophe tapering, consistent with Type I pattern; $1-4$ pairs of ridges terminate on lateralmost ridge anterior to EIJ; cervical papillae adjacent to lateralmost ridges in right and left fields. Ventral/dorsal ridge systems parallel, consistent with Type B pattern. Sublateral/ventral fields in cervical zone with $2-4$ continuous ridges $(n=5)$ that may assume lateral or ventral orientation; continuous ridges may diverge or remain parallel; 4 of 5 specimens with 2 continuous ridges in sublateral/ventral fields. Lateral ridges and ventral/dorsalmost ridge $(n=3)$ extend anteriad to level of cephalic expansion. Tapering pattern extends $(\mathrm{n}=13) 38-61 \%$ $(52 \% \pm 5.6 \%)$ of total length from anterior. In transverse section (1 male and 1 female, respectively) ridges number from the anterior 56 and 51 at EIJ (51-58 based on counts of fields in cervical reconstructions in 3 whole nematodes); 60 and 53 at 1/4; 56 and 46 at midbody; 58 and 49 at 3/4, with initial loss in dorsal/ventral fields; and 44 ridges in the male at a level anterior to the spicules. Synlophe terminates anterior to bursa in males and anus in females. In females, ridges terminate laterally $62-212$ and dorsoventrally $102-220$ anterior to anus. In males ridges terminate laterally at 75-250 and dorsoventrally at 192525 anterior to the prebursal papillae.
Male: Small nematodes with prominent copulatory bursa; discrete fields of bursal bosses lacking. Total length $(\mathrm{n}=10) 6,350-8,555$ (7,471 \pm 642.7); maximum width 115 attained at level near prebursal papillae. Esophagus $(n=11) 688-825(757 \pm 49.6)$ long; 9.4-11.3\% of total body length. Valve at EIJ cylindrical, longer than wide $(\mathrm{n}=$ 10) $80-98(91 \pm 5.5)$ in length by $(\mathrm{n}=10) 48-75(56 \pm 7.93)$ in maximum width. SVGO $(\mathrm{n}=10) 230-310(276 \pm 25.15)$, EXP $(\mathrm{n}=$ 10) 305-421 (370 \pm 31.2$), \mathrm{CP}(\mathrm{n}=11) 330-445$ (395 \pm 32.04$)$ from cephalic extremity. Copulatory bursa symmetrical, of type $2-2-1$. Rays $2 / 3$ curved, divergent through midlength, convergent distally, extending to margin of bursal membrane; Rays 3 with massive base. Rays $4 / 5$ parallel through length, highly divergent distally, relatively narrow; length of Ray $4 \leq$ Ray 5; Ray 4 not extending to margin of bursa. Rays 6 attaining margin of bursa, relatively straight, curved distally. Accessory bursal membrane, simple, deeply incised, strongly bilobed, containing narrow, filamentous, weakly curved papillae "7." Rays 8, massive curved mediad, extending to margin of bursa. Dorsal lobe massive, reduced in length, laterally and dorsally inflated with prominent cuticular striations on dorsal aspect, weakly incised on ventral aspect, curving ventrally to externodorsal rays, containing massive Rays 9/10 with stout, expanded base proximally, positioned ventral relative to Rays 8 $(n=3) 33-41$ in length with primary bifurcation at 18-28 from base, or in distal half at $54-68 \%$ from anterior; paired phasmids directed ventrolaterally, and papillae $9 / 10$ on bifurcate distal tips of dorsal ray. Bursal membrane adjacent to dorsal lobe with region of curved thickened cuticle along medial margin. Genital cone with weakly developed

FIGURES 2-7. Africanastrongylus buceros gen. nov. et sp. nov., showing structure of synlophe based on photomicrographs of transverse sections in a male (2-4) and a female (5-7) paratype (series USNPC 66322); the general orientation is perpendicular and a gradient in size is not evident, although the lateralmost ridges are miniscule relative to those in adjacent fields. (2) Synlophe in male at esophageal-intestinal junction showing 56 ridges. (3) Synlophe in male at midbody showing 56 ridges. (4) Synlophe at beginning of third quarter in male showing 58 ridges. (5) Synlophe in female at esophageal-intestinal junction showing 51 ridges. (6) Synlophe in female at midbody showing 46 ridges. (7) Synlophe at beginning of third quarter in female showing 49 ridges. 


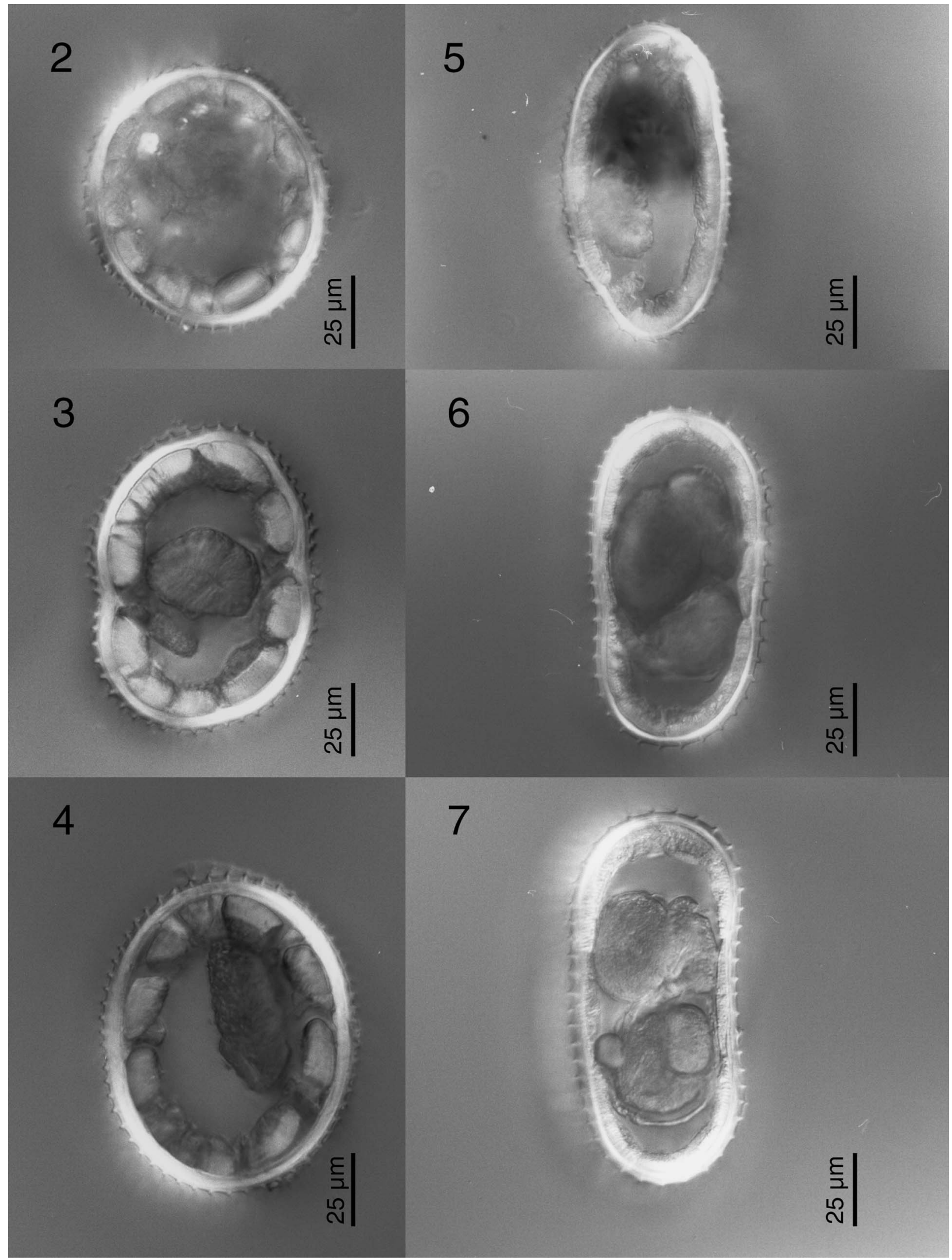




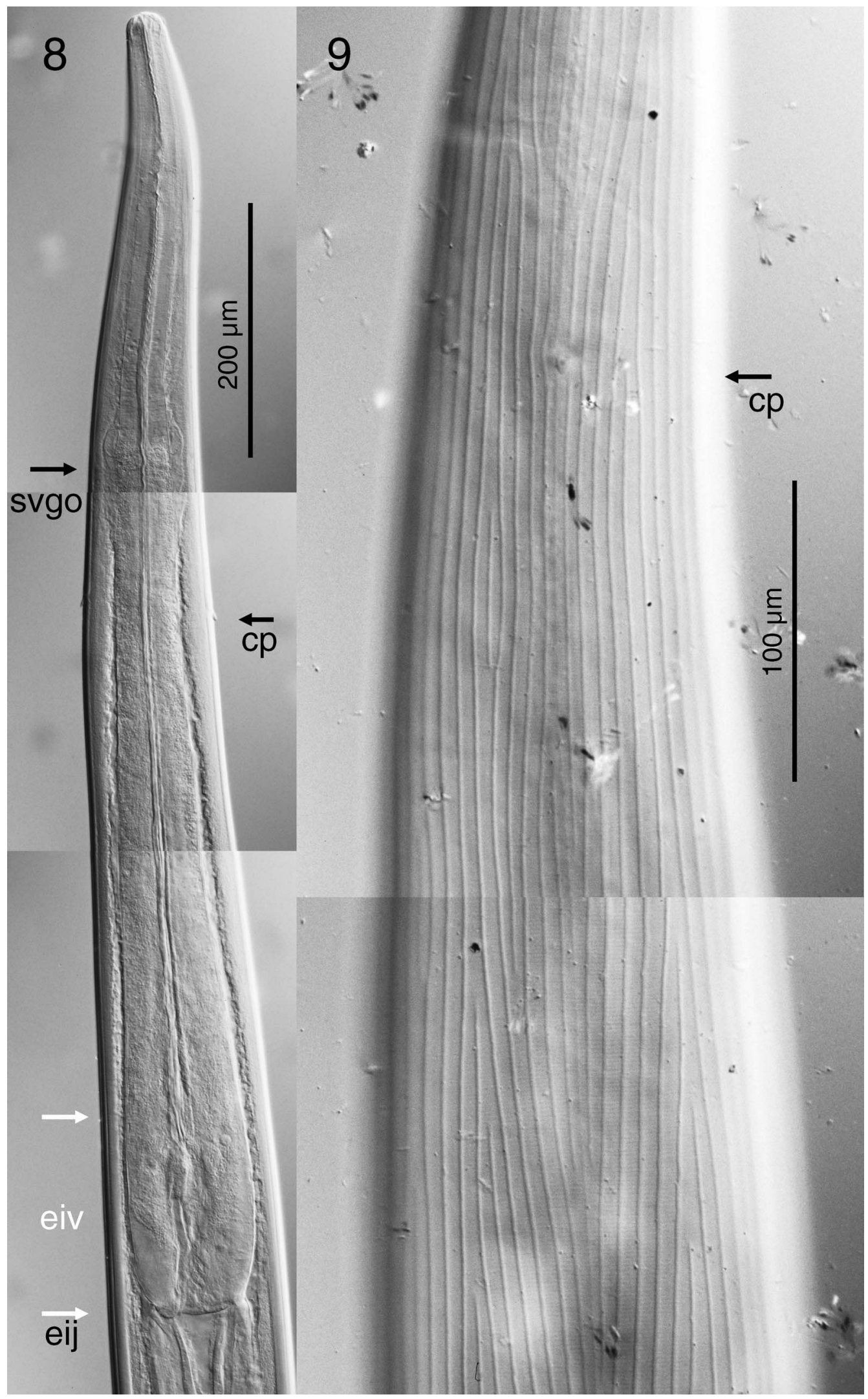

FigURES 8-9. Africanastrongylus buceros gen. nov. et sp. nov., showing cervical and cephalic attributes based on photomicrographs. (8) Cervical zone in ventral view of a male paratype (USNPC 66322) denoting the position of the subventral gland orifices (svgo), cervical papillae (cp), esophageal-intestinal valve (eiv) and esophageal-intestinal junction (eij); note slight bulbous expansion of basal valve and esophagus. (9) Cervical synlophe in a female paratype (USNPC 99549) showing lateral view from near base of cephalic expansion in anterior to base of esophagus in posterior, showing Type-I tapering lateral pattern relative to miniscule lateralmost ridge and cervical papilla (cp). 


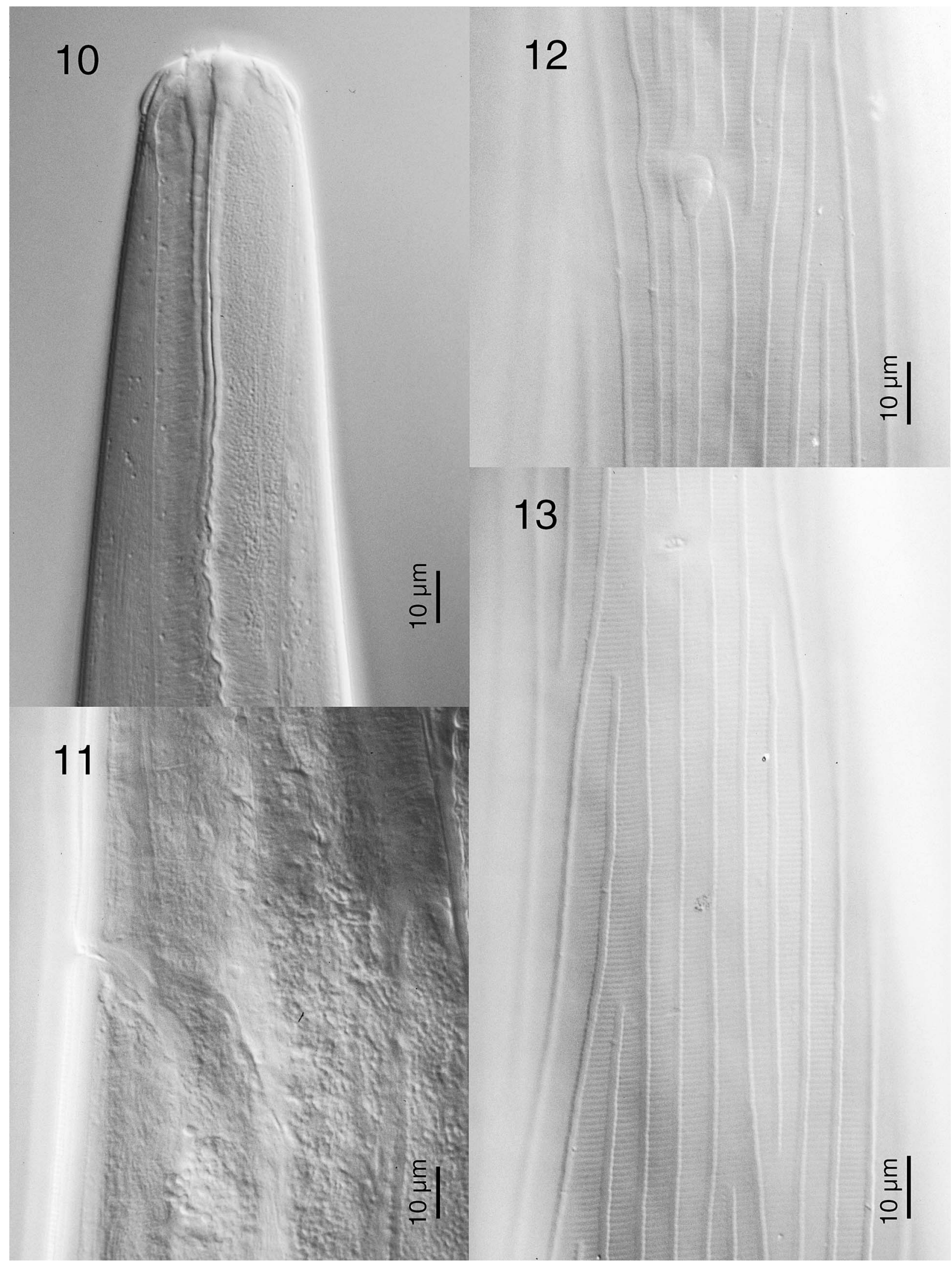

FIGURES 10-13. Africanastrongylus buceros gen. nov. et sp. nov., cervical and cephalic attributes based on photomicrographs in a female paratype (USNPC 99551). (10) Cephalic extremity in left lateral view. (11) Excretory pore in lateral view in a female specimen, showing absence of ornamentation. (12) Cervical papilla, showing thornlike structure and position relative to the lateralmost ridge and the cervical synlophe. (13) Excretory pore in ventral view in a female specimen, showing absence of ornamentation, and position on ventralmost ridge. 
14

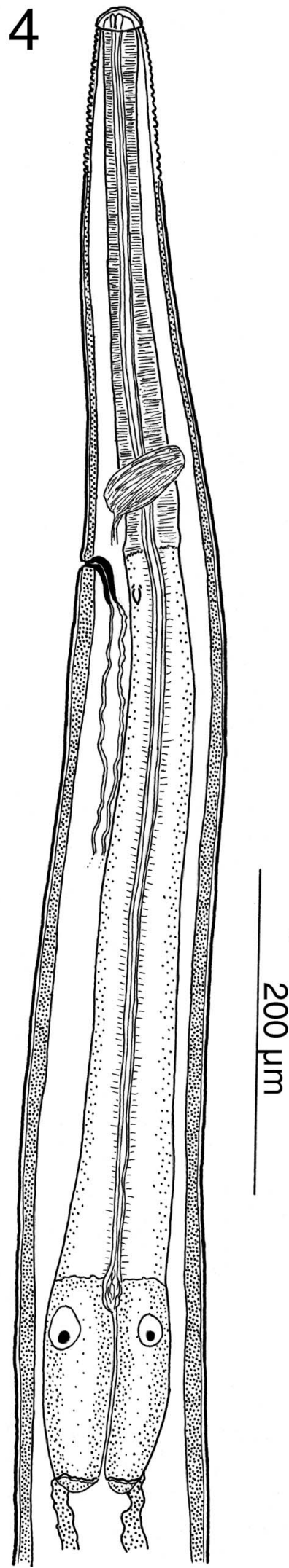

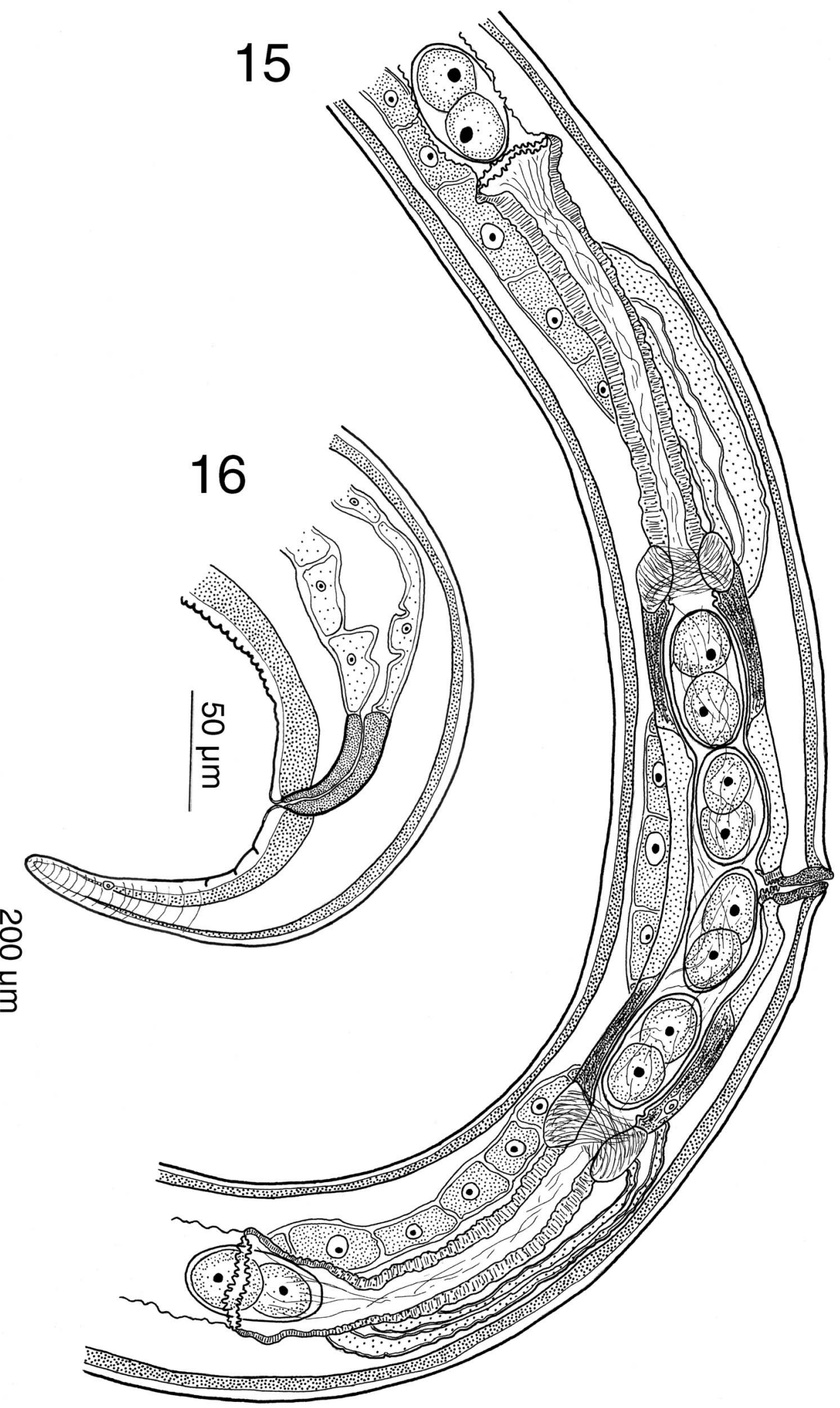

FiguRES 14-16. Africanastrongylus buceros gen. nov. et sp. nov., showing female attributes as depicted in line drawings from paratype specimens (USNPC 99551). (14) Cephalic and cervical zone in left lateral view. (15) Ovijectors in right lateral view (same scale as Figure 14). (16) Tail and anus in left lateral view. 


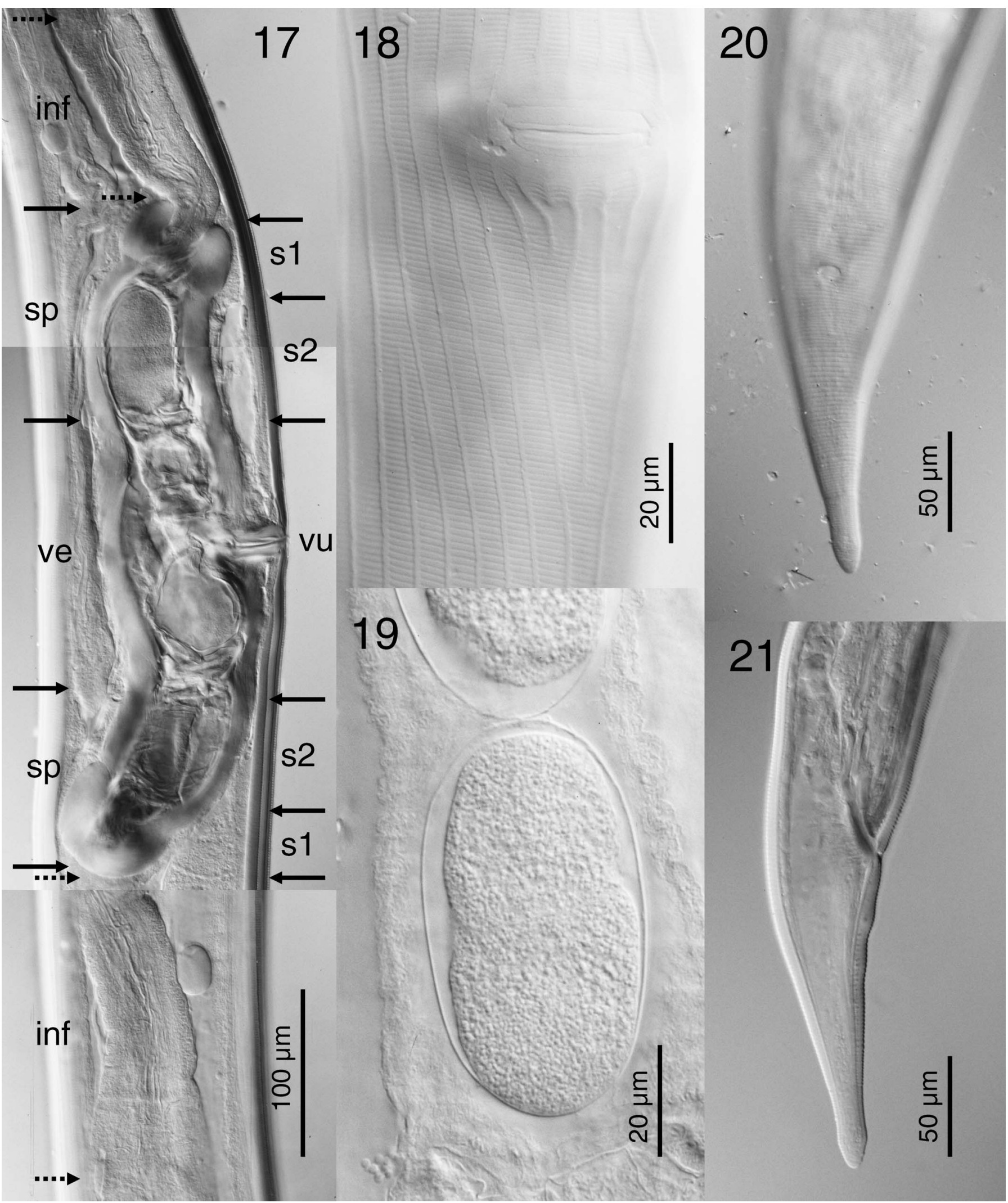

FiguRES 17-21. Africanastrongylus buceros gen. nov. et sp. nov., showing structural characters of females based on photomicrographs. (17) Ovijectors in right lateral view of a paratype (USNPC 66322), showing form and relative dimensions of the infundibula (inf, between dotted arrows), sphincters (sp) including the bulblike sphincter-1 (s1) and elongate sphincter-2 (s2), vestibule (ve), and transverse vulva (vu), lacking ornamentation. (18) Vulva, ventral view in a paratype (USNPC 99551), showing transverse structure and adjacent synlophe. (19) Eggs with thin shell in utero from a paratype (USNPC 99551). (20) Tail and anus in ventral view of a paratype (USNPC 99548). (21) Tail and anus in lateral view, showing slight bulbous expansion of apex. 

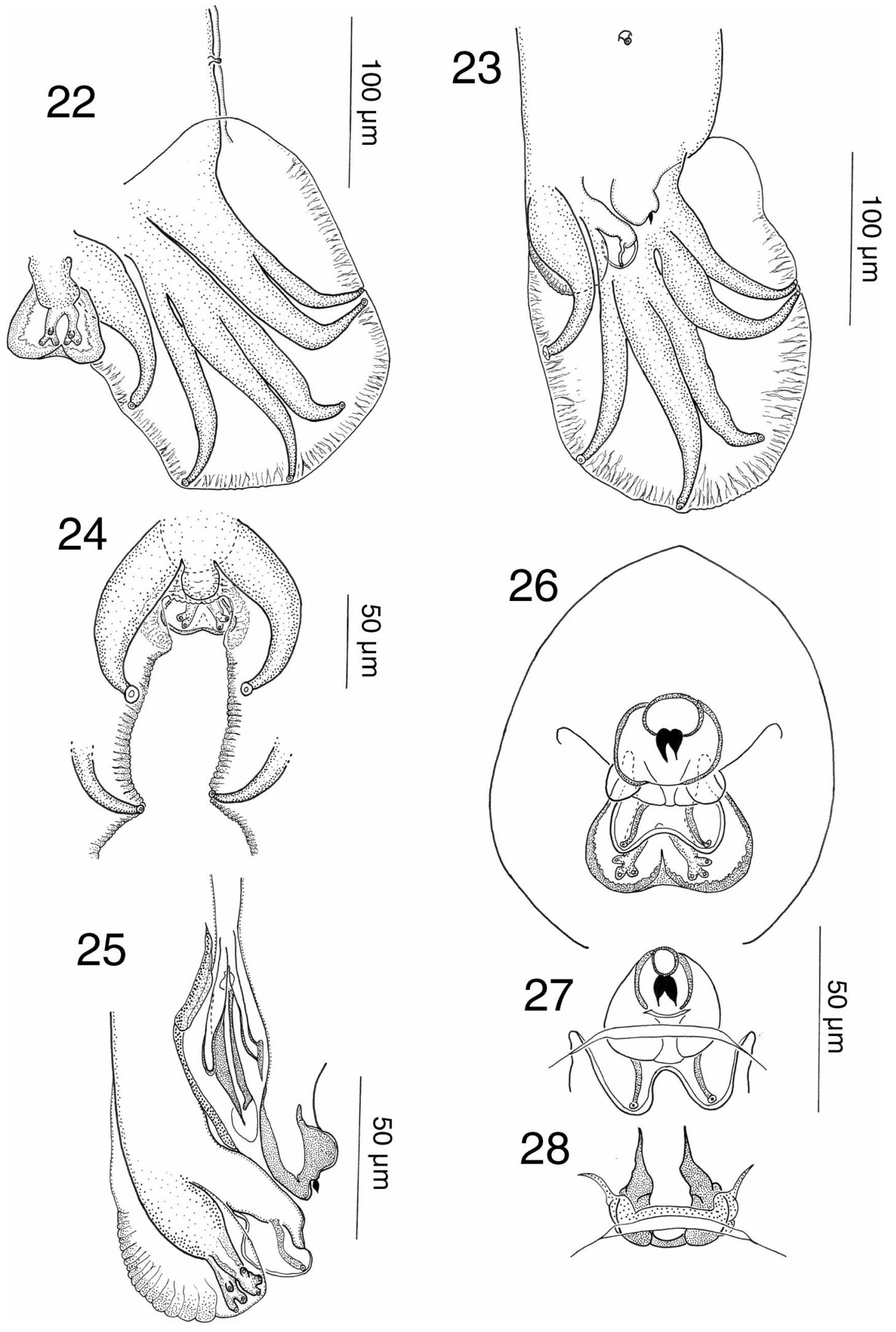
proconus; paired " 0 " papillae with broadened bases proximally, miniscule, positioned posterior to proconus on ventral aspect of cloaca. Cloaca with telamon and cuticularized support structures surrounding orifice. Spicules subequal, left spicule longer in 12 of 13 specimens; left $(\mathrm{n}=14)$ 195-246 (212 \pm 14.1$)$; right $(\mathrm{n}=13)$ 190-240 (207 \pm 15.2). Spicules, alate, narrow, weakly curved, filamentous in lateral view. Spicules trifurcate with acutely pointed main process, curved mediad, terminating distally in simple bulbous membrane; ventral and dorsal processes originating at level of "ostertagiine window" $76-83 \%$ of total length from anterior. Ventral process terminating in triangular barb; dorsal process terminating in narrow rounded point; length of dorsal $<$ ventral process. Gubernaculum alate, shieldlike, concave ventrally, strongly cuticularized, with hornlike extensions on proximal margin, maximum width in dorsoventral view $(\mathrm{n}=10) 35-42(38 \pm 1.8)$, tapering distally; in lateral view weakly $\mathrm{S}$ shaped, length $(\mathrm{n}=12) 60$ $82(67 \pm 5.9)$

Female: Small nematodes lacking prominent cuticular ornamentation other than synlophe. Total length $(\mathrm{n}=18) 9,712-12,610(11,217 \pm$ 909.5); maximum width 140 attained at level anterior to vulva. Esophagus $(\mathrm{n}=18)$ 775-905 $(834 \pm 33.7)$ long; $6.4-8.7 \%(7.5 \pm 0.7)$ total body length. Valve at EIJ (17) 92-112 (101 \pm 5.8) long, (17) 45-74 $(66 \pm 8.2)$ in maximum width. SVGO (17) 285-342 (306 \pm 13.9$)$, EXP (18) 305-482 (394 \pm 54.6), and CP (18) 320-545 (421 \pm 63.5) from cephalic extremity. Ovaries didelphic. Vulva opens as ventral transverse slit $(\mathrm{n}=18) 79-85 \%(82 \pm 2.0)$ of body length from anterior; cuticular inflations and fans absent. Perivulvar pores bilateral, located 195-205 posterolateral to vulva in subventral fields. Anterior infundibulum $(\mathrm{n}=$ 11) 185-292 (240 \pm 30.8$)$, anterior sphincter, including $\mathrm{s} 1$ and $\mathrm{s} 2(\mathrm{n}=$ 13) $110-192(149 \pm 24)$. Posterior infundibulum $(n=11) 170-267$ (231 \pm 26.1$)$, posterior sphincter, including s1 and s2 $(n=13) 98-162$ $(140 \pm 16.7)$. Vestibule length $(n=13) 70-205(144 \pm 42.3$. Total ovijector length $(\mathrm{n}=10) 795-1,016(911 \pm 77.1)$. Eggs ovoid, with thin shell ( $\mathrm{n}=90$ in 9 specimens) $62-82(72 \pm 5.9)$ long by $30-50$ $(41 \pm 4.2)$ wide, oriented in single rows in anterior and posterior uterine limbs. Tail digitate, weakly inflated distally, lacking prominent annulations adjacent to tip, lacking synlophe, 142-218 (167 \pm 19.8$)$ in length.

\section{Taxonomic summary}

Host: African buffalo, S. caffer caffer (Sparrman), type and only known host.

Localities: Type locality: In type host at Anaka Village, West Acholi District, Uganda; ca. $02^{\circ} 45^{\prime} \mathrm{N}, 032^{\circ} 10^{\prime} \mathrm{E}$. Additional localities: (1) Queen Elizabeth National Park, Toro District, Uganda; ca. $00^{\circ} 19^{\prime} \mathrm{N}$, $032^{\circ} 058^{\prime} \mathrm{E}$; (2) Mpala Ranch, Kenya, $00^{\circ} 17^{\prime} \mathrm{N}, 036^{\circ} 53^{\prime} \mathrm{E}$; (3) HluhluweiMfolozi Park, KwaZulu-Natal, South Africa, $28^{\circ} 00^{\prime}$ S, $031^{\circ} 43^{\prime} \mathrm{E}$.

Specimens: Holotype male, USNPC 99545, in host No. 11 from type locality. Allotype female, USNPC 99546 in host No. 33 from Queen Elizabeth National Park, Uganda. Paratypes include (1) USNPC 66322.02, 7 males and 7 females in host No. 11; (2) USNPC 99551, 5 males and 2 females in host No. 33; (3) USNPC 99547, 5 females in host BN1-200, from the Mpala Ranch, Kenya; (4) USNPC 99548, 2 males and 1 female from host B13 at Hluhluwe-iMfolozi Park, South Africa; (5) USNPC 99549, 2 females from host C72 at HluhluweiMfolozi Park, South Africa. Vouchers, USNPC 86939, include 2 female nematodes in host No. 33.

Etymology: Africanastrongylus is derived from the Latin, Afer for African, and from the Greek strongylos for round, denoting a nematode or roundworm from Africa. The species name, buceros, is derived from the New Latin and Greek boukeros for oxlike horns, denoting the hornlike extensions on the anterior margin of the gubernaculum of the male, and a host in the subfamily Bovinae.

\section{Remarks}

Hoberg and Lichtenfels (1994) provided the first phylogenetic hypothesis for the monophyly of the Ostertagiinae and its relationship to the Haemonchinae within what was named the Graphidiinae clade. Conclusions from this study were corroborated by Durette-Desset et al. (1999) in demonstrating monophyly for the subclade, but with inclusion of Graphidium Raillet and Henry, 1909 as the basal taxon in the Ostertagiinae. In this interpretation, the previously recognized Graphidiinae subclade is equivalent to the proposed Haemonchidae for the sister taxa Ostertagiinae + Haemonchinae (Hoberg and Lichtenfels, 1994; Durette-Desset et al., 1999). We would suggest that inclusion of Graphidium remains problematic and is not otherwise compatible with Ostertagiinae.

A morphological and phylogenetic diagnosis for the Ostertagiinae within Trichostrongyloidea and relative to their haemonchine sister group includes: (1) tripartite spicule tips; (2) spicules with an "ostertagiine window (a foramenlike structure that is visible at point of trifurcation for the primary, dorsal and ventral processes of the spicule tips);" (3) paired "0" papillae; (4) membranous and simple accessory bursal membrane containing filamentous " 7 " papillae (modified in minor morphotypes for males of polymorphic species, e.g., Dróżdż, 1995); and (5) prominent esophageal valve separating the basal esophagus from the intestine. Additionally, other diagnostic characters exhibit some level of homoplasy, including (1) a vulva with cuticular ornamentation in the form of irregular inflations (Hoberg et al., 1993a); (2) genera characterized by species with polymorphic males (Dróżdż, 1995); and (3) certain tapering patterns of the cervical synlophe appear limited to taxa within the subfamily, but overall are not indicative of monophyly (e.g., Lichtenfels et al., 1988; Lichtenfels and Hoberg, 1993; Lichtenfels et al., 1993; Hoberg, 1996). A suite of putative synapomorphies proposed for the Ostertagiinae is not represented in Graphidium, and placement of this taxon may require further consideration, but is beyond the scope of the current study.

Currently, a maximum of 12 genera, diagnosed by a suite of attributes outlined above, are represented among the Ostertagiinae. Clarification for generic-level taxonomy of the ostertagiines was recently proposed (Hoberg and Abrams, 2007) in the context of a revision involving Sarwaria caballeroi (Chabaud, 1977). The basis for the taxonomy in the current article in part adopts facets of different proposals for synonymies and the validity of certain taxa (e.g., Andreeva, 1956; Dróżdż, 1965; Durette-Desset and Chabaud, 1981; Durette-Desset, 1982; Gibbons and Khalil, 1982a; Durette-Desset, 1983, 1985, 1989; Jansen, 1989; Durette-Desset et al., 1999). Fundamental differences in bursal structure and the patterns for Rays 2/3, Rays 4/5, and Rays 6 serve to distinguish larger inclusive groups within the subfamily (Durette-Desset, 1983; Durette-Desset et al., 1999).

Among the Ostertagiinae, 6 genera are characterized by a bursal pattern of 2-1-2 (Camelostrongylus Orloff, 1933; Longistrongylus LeRoux, 1931; Marshallagia (Orloff, 1933), Orloffia Dróżdż, 1965; Ostertagia Ransom, 1907; and Pseudomarshallagia (Roetti, 1941)). Alternatively, a $2-2-1$ pattern is typical among 6 genera (Cervicaprastrongylus Gibbons and Khalil, 1982; Hyostrongylus Hall, 1921; Mazamastrongylus Cameron, 1935; Sarwaria Dróżdż, 1965; Spiculop-

FiguRes 22-28. Africanastrongylus buceros gen. nov. et sp. nov., showing bursa and genital cone in male as depicted in line drawings of the holotype and paratypes. (22) Bursa, left lobe in ventral view of a paratype (USNPC 66322) showing 2-2-1 pattern of lateral rays, massive base for Rays 8, ventral disposition for inflated dorsal lobe and reduced Rays 9/10. (23) Bursa in right lateral view of a paratype (USNPC 66322) showing 2-2-1 pattern, miniscule proconus, simple accessory bursal membrane containing " 7 " papillae and ventral disposition of the dorsal lobe. (24) Dorsal (Rays 9/10) and externodorsal rays (Rays 8) in dorsal view of a paratype (USNPC 66322); note massive bases for Rays 8, robust or stout base of dorsal ray, and lateral thickenings of bursal membrane adjacent to the dorsal lobe. (25) Genital cone in right lateral view of a paratype (USNPC 66322) showing inflated dorsal lobe with robust but reduced Rays 9/10, accessory bursal membrane with "7" papillae, "0" papillae, and proconus. (26) Genital cone in ventral view of holotype (USNPC 99545) showing paired " 0 " papillae, incised or bilobate accessory bursal membrane and laterally inflated, ventrally incised, dorsal lobe and reduced Rays 9/10. (27) Genital cone in ventral view of a paratype (USNPC 66322). (28) Telamon and cuticularized support structure at cloaca in ventral view of a paratype (USNPC 66322) (same scales for Figs. 25-27). 

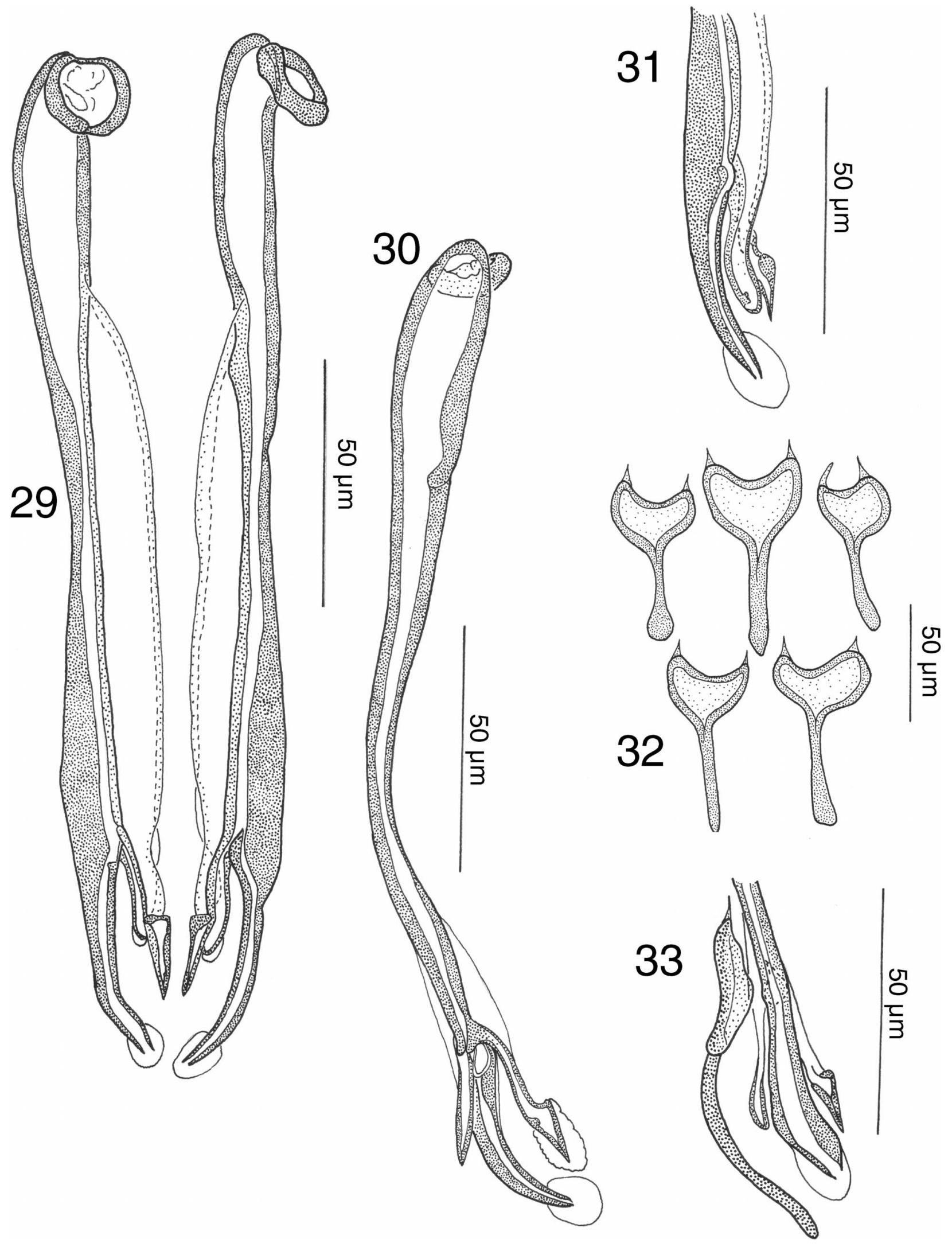
teragia (Orloff, 1933); and Teladorsagia Andreeva and Satubaldin, 1954); further criteria for, and validity of, Cervicaprastrongylus, Mazamastrongylus, and Sarwaria, are reviewed elsewhere (Gibbons and Khalil, 1982b; Lichtenfels et al., 1993; Hoberg, 1996; Lichtenfels et al., 1996; Hoberg and Abrams, 2007).

Africanastrongylus gen. nov. is immediately distinguished from all species of Camelostrongylus, Longistrongylus, Marshallagia, Orloffia, Ostertagia, and Pseudomarshallagia by the structure of the 2-2-1 bursa in males (Durette-Desset, 1983); note the concept for Camelostrongylus as proposed by Durette-Desset (1989) that subsumes many species of Ostertagia within this genus is not accepted here. Among this group of genera, species of Longistrongylus typically possess narrow filamentous spicules and a substantially reduced dorsal lobe and ray (Gibbons, 1972, 1973, 1977) that appear superficially similar to A. buceros. Among species of Longistrongylus, based on descriptions and examination of some representatives (Table I), the reduced lobe is not strongly inflated laterally or dorsally and remains in a dorsal position relative to the externodorsals or Rays 8 . The dorsal ray, although stout, is narrow at the base and the bursa contains numerous and discrete fields of bosses. The "0" papillae are filamentous, of constant diameter, highly divergent, disposed in an arcuate pattern, terminate in bulbous expansions, and are enclosed in a bilobed membrane; a proconus is consistently absent. Further, the accessory bursal membrane in species of Longistrongylus is highly reduced or modified, and is not simple or membranous, as seen in Africanastrongylus. Females of all species of Longistrongylus are characterized by irregular cuticular inflations at the level of the vulva (Hoberg et al., 1993a).

Gibbons (1977) reviewed Longistrongylus and proposed synonymies for Kobusinema Ortlepp, 1963 and Bigalkenema Ortlepp, 1963. The bursal pattern in species once referred to Bigalkenema, namely, Longistrongylus sabie (Mönnig, 1932), Longistrongylus curvispiculum (Gibbons, 1973), and Longistrongylus namaquensis (Ortlepp, 1963) approaches a 2-2-1; however, the distal tips of Rays 4, 5, and 6 are all highly divergent, the dorsal lobe is not strongly defined, and the bases of Rays 8 and the dorsal ray are not massive (Mönnig, 1933; Ortlepp, 1963; Gibbons, 1973, 1977).

Among ostertagiines with a 2-2-1 bursa, Africanastrongylus buceros can be distinguished in the following manner. In Spiculopteragia and Mazamastrongylus, the absence of a proconus, Rays $4<5$ in length, robust Rays 4, presence of a unique hood-ridge system in the ventral cervical synlophe, and a liplike and protruding excretory pore (Andreeva, 1958; Lichtenfels et al., 1993; Hoberg, 1996; Hoberg and Khrustalev, 1996) differentiate these genera from Africanastrongylus. Further, among species of Spiculopteragia, males are polymorphic and spicules are adorned with prominent fanlike membranes. In Cervicaprastrongylus and Hyostrongylus, the structure of the parallel cervical synlophe (Type 2 lateral), absence of a proconus, a bursa with Rays 4/5 parallel and not divergent distally, elongate Rays 8 , and an elongate dorsal ray (Gibbons and Khalil, 1982a, 1982b; Durette-Desset et al., 1992; Hoberg et al., 1993b) contrast with this suite of attributes in Africanastrongylus. Compared to Teladorsagia, polymorphism among males, a robust Rays 4 , an elongate dorsal ray and lobe, elongate and relatively straight Rays 8, and absence of a proconus (Andreeva, 1956, 1958; Dróżdż, 1965, 1995; Hoberg et al., 1999) represent consistent differences relative to Africanastrongylus.

Africanastrongylus buceros is morphologically similar but distinct from species of Sarwaria. Species of both genera are characterized by a tapering, Type 1, lateral synlophe, miniscule but thornlike cervical papillae, and a reduced but laterally inflated dorsal lobe disposed ventrally to Rays 8 (Lichtenfels et al., 1996; Hoberg and Abrams, 2007). In Africanastrongylus, Rays $2 / 3$ are initially divergent and distally convergent, whereas Rays $4 / 5$ are subequal in length, parallel through their length, and divergent distally; Rays 8 are massive and medially curved, and both a proconus and gubernaculum are present. Sarwaria, including Sarwaria bubalis (Sarwar, 1956) and S. caballeroi (Chabaud, 1977), however, contrasts in having Rays $2 / 3$ weakly divergent along their entire length, Rays $4<5$ in length, a robust Rays 4 , a relatively elongate, narrow and straight Rays 8, and both a proconus and gubernaculum are absent (Dróżdż, 1965; Chabaud, 1977; Hoberg and Abrams, 2007). We propose Africanastrongylus as a previously unrecognized genus that is morphologically consistent with placement among the Ostertagiinae.

Among a diverse global assemblage, including 24 species and 7 genera of ostertagiines known from the African fauna (Table II), A. buceros gen. nov. et sp. nov. must also be differentiated from 2 problematic species, namely, Ostertagia kenyensis Gibbons and Khalil, 1980 in Damara Dik Dik (Madaqua kirkii Günther) and Grant's gazelle (Gazella granti Brooke) and Teladorsagia hamata (Mönnig, 1932) in Springbok (Antidorcas marsupialis (Zimmerman)) and Bontebok (Damaliscus pygargus (Pallas)). The latter species, originally described in Ostertagia Ransom, 1907, was later transferred to Spiculopteragia Orloff, 1933 by Travassos (1937), to Apteragia Jansen, 1958 by Jansen (1958), and most recently to Teladorsagia Andreeva and Satubaldin, 1954 by DuretteDesset (1989). Gibbons and Khalil (1980) recognized the similarity of these nematodes, both with a $2-2-1$ bursal formula, and distinguished $O$. kenyensis based on the configuration of the dorsal process of the spicules (lacking a prominent hooklike structure), and weakly curved and parallel Rays $4 / 5$.

Paratype specimens of $O$. kenyensis, and a syntype male specimen of T. hamata, were in general agreement with original descriptions (Mönnig, 1932; Gibbons and Khalil, 1980). Observations of the structure of the synlophe and other attributes in T. hamata are limited to the single specimen available to us and the original description (Mönnig, 1932). Other type and voucher specimens of $T$. hamata were unfortunately lost in transit to the USNPC from the Onderstepoort Helminthological Collection.

New data on structural attributes of the synlophe, bursa, and spicules are partially described based on these specimens of $O$. kenynesis and T. hamata. The lateral synlophe in the cervical region is parallel and Type 2 and the cervical papillae are massive and thornlike; a greater number of ridges characterize T. hamata (Mönnig, 1932; Gibbons and Khalil, 1980). Overall, the structure and configuration of the bursa and bursal rays and dorsal lobe is similar; "7" papillae are contained in an accessory bursal membrane that is reduced and inconspicuous. The spicules are robust and massive, resembling those characteristic of minor morphotypes among the ostertagiines (Dróżdż, 1995) and have a simple ventral process and modified dorsal process. Additionally, spicules in paratypes of $O$. kenyensis were characterized by a weakly developed barb on the curved dorsal process, which is not visible in all orientations. Although these species exhibit extensive overlap in some meristic characters (Mönnig, 1932; Gibbons and Khalil, 1980; Tables III, IV), they can be unequivocally distinguished. We conclude the $O$. kenyensis and T. hamata are morphologically similar congeners representing an undetermined genus among the ostertagiines; a taxonomic decision regarding these species is deferred, and is considered beyond the scope of the current study.

Together with $A$. buceros, specimens of $O$. kenyensis and $T$. hamata share a suite of characters, including a bursal formula of $2-2-1$, where Rays $4 / 5$ are subequal to equal in length, parallel, relatively straight and narrow, and which diverge distally at the tips adjacent to the bursal margin; Rays 2/3 are divergent throughout and become convergent distally. The dorsal lobe is strongly reduced, and curves ventrally relative to Rays 8 and the dorsal ray, or Rays $9 / 10$, bifurcate in the distal half. In $O$. kenyensis the bursal margin adjacent to the dorsal lobe is thick-

$\leftarrow$

FiguRES 29-33. Africanastrongylus buceros gen. nov. et sp. nov., showing spicules and gubernaculum depicted in line drawings in the male holotype and paratypes. (29) Spicules in ventral view of holotype (USNPC 99545) showing alate structure with medially curved main processes, triangular ventral processes and simple, weakly pointed to rounded dorsal processes. (30) Spicule, left, in mediolateral view of paratype (USNPC 66322) showing bent or kinked main shaft, trifurcation of dorsal and ventral processes and the ostertagiine window. (31) Spicule, left, in dorsal view of a paratype (USNPC 66322) showing rounded, weakly pointed dorsal process. (32) Gubernaculum in ventral view of paratypes (USNPC $66322,99548,99551$ ) showing shieldlike structure in anterior and hornlike processes consistent among all male specimens. (33) Gubernaculum and spicule in right lateral view of paratype (USNPC 66322) showing weakly S-shaped structure and relative positions. 


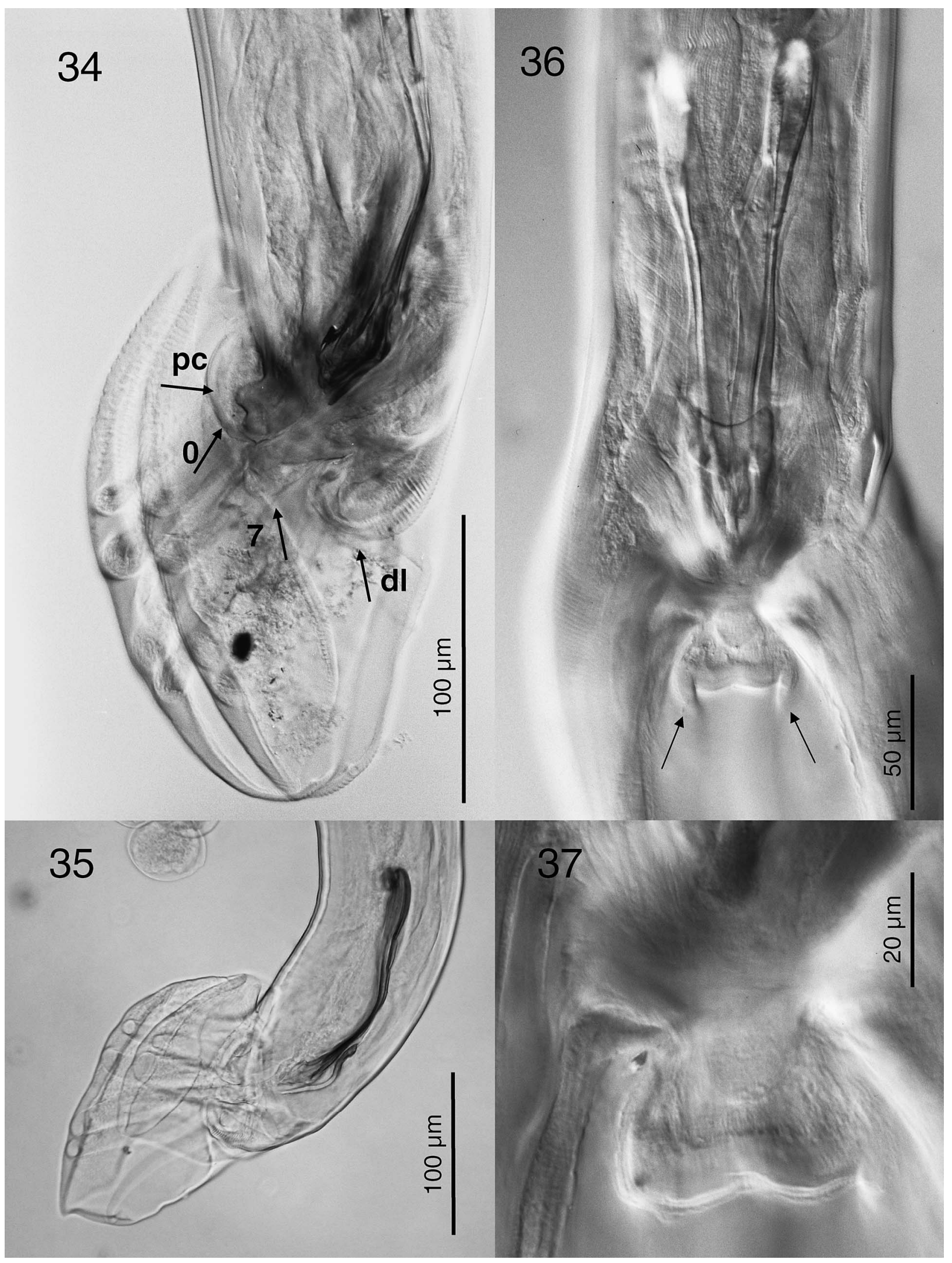

FIGURES 34-37. Africanastrongylus buceros gen. nov. et sp. nov., showing male bursal attributes based on photomicrographs of paratypes. (34) Bursa in left lateral view (USNPC 66322) showing position of proconus (pc), "0" papillae (0), accessory bursal membrane and "7" papillae (7), and ventrally disposed dorsal lobe (dl). (35) Bursa in lateral view (USNPC 99548) showing bend in spicules and S-shaped gubernaculum. (36) Bursa in dorsal view (USNPC 66322) showing disposition of narrow, filamentous spicules, shieldlike anterior of gubernaculum, dorsal lobe, and lateral thickening of bursal membrane (arrows). (37) Dorsal lobe in ventral view (USNPC 66322) showing laterally inflated form and incision. 


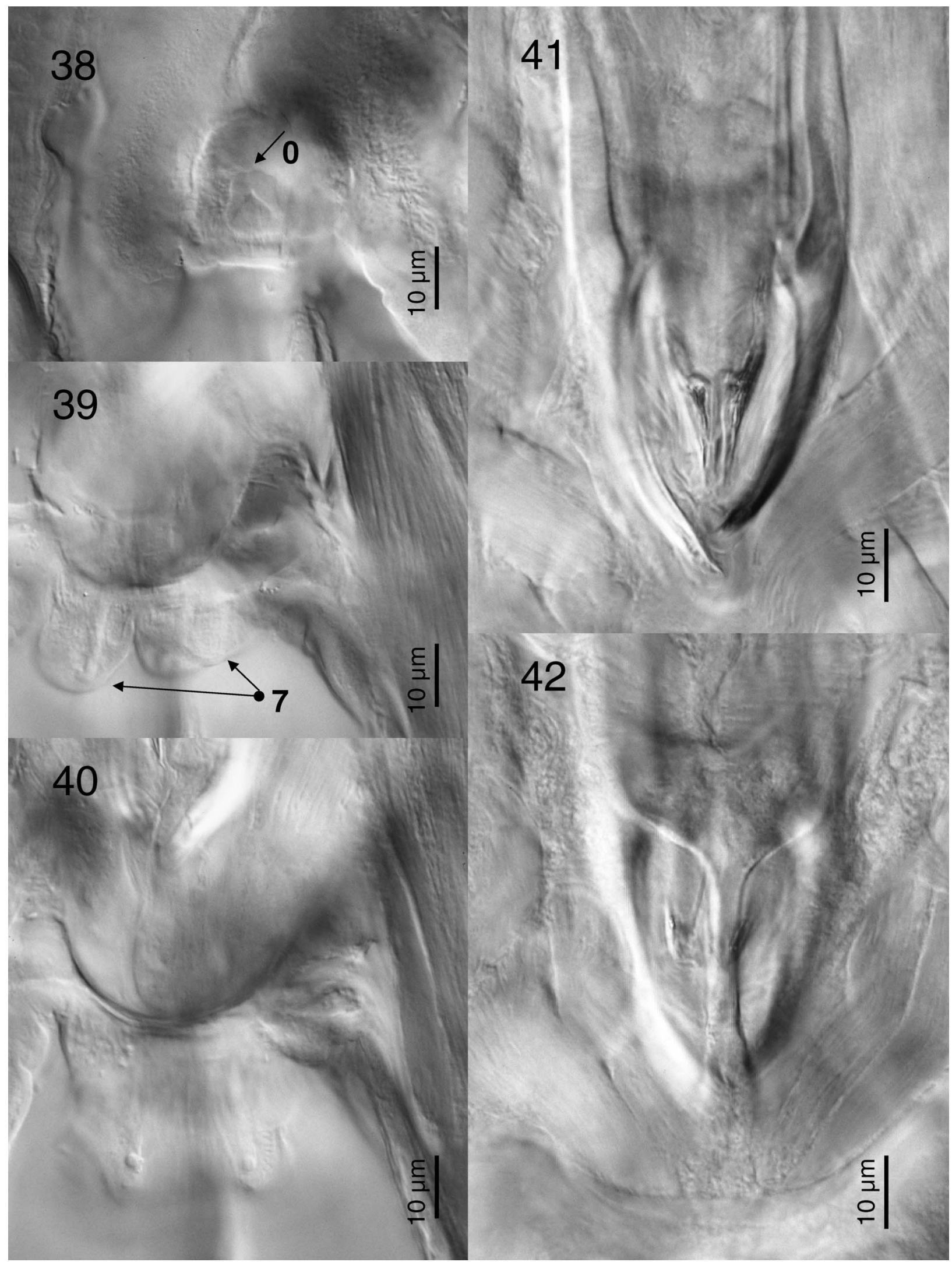

FigURES 38-42. Africanastrongylus buceros gen. nov. et sp. nov., showing genital cone in male based on photomicrographs of holotype (USNPC 99545). (38) 0 papillae paired, ventral view (Figs. 38-40 are sequential from ventral to dorsal through single specimen). (39) Accessory bursal membrane in ventral view showing straight, filamentous "7" papillae (7) and bilobate or incised structure. (40) Dorsal lobe and Rays 9/10 in ventral view showing ventrally directed papillae near terminus of short, stout ray. (41) Spicule tips in ventral view showing triangular structure at termination of ventral processes and medially curved main shafts capped with hyaline tips. (42) Gubernaculum and dorsal processes of spicules in dorsal view; note plate or shieldlike structure of anterior gubernaculum and simple termination of dorsal processes. 


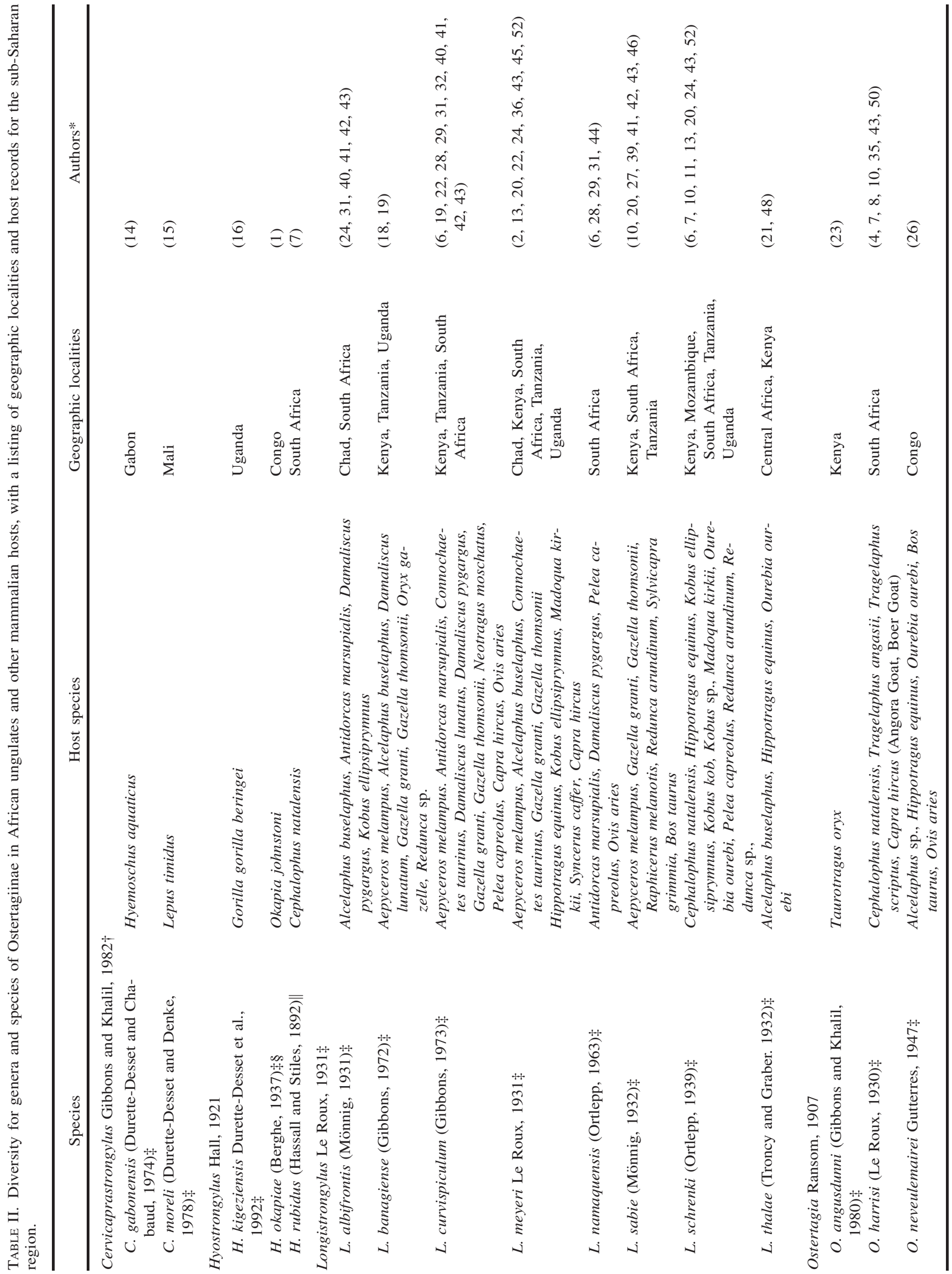




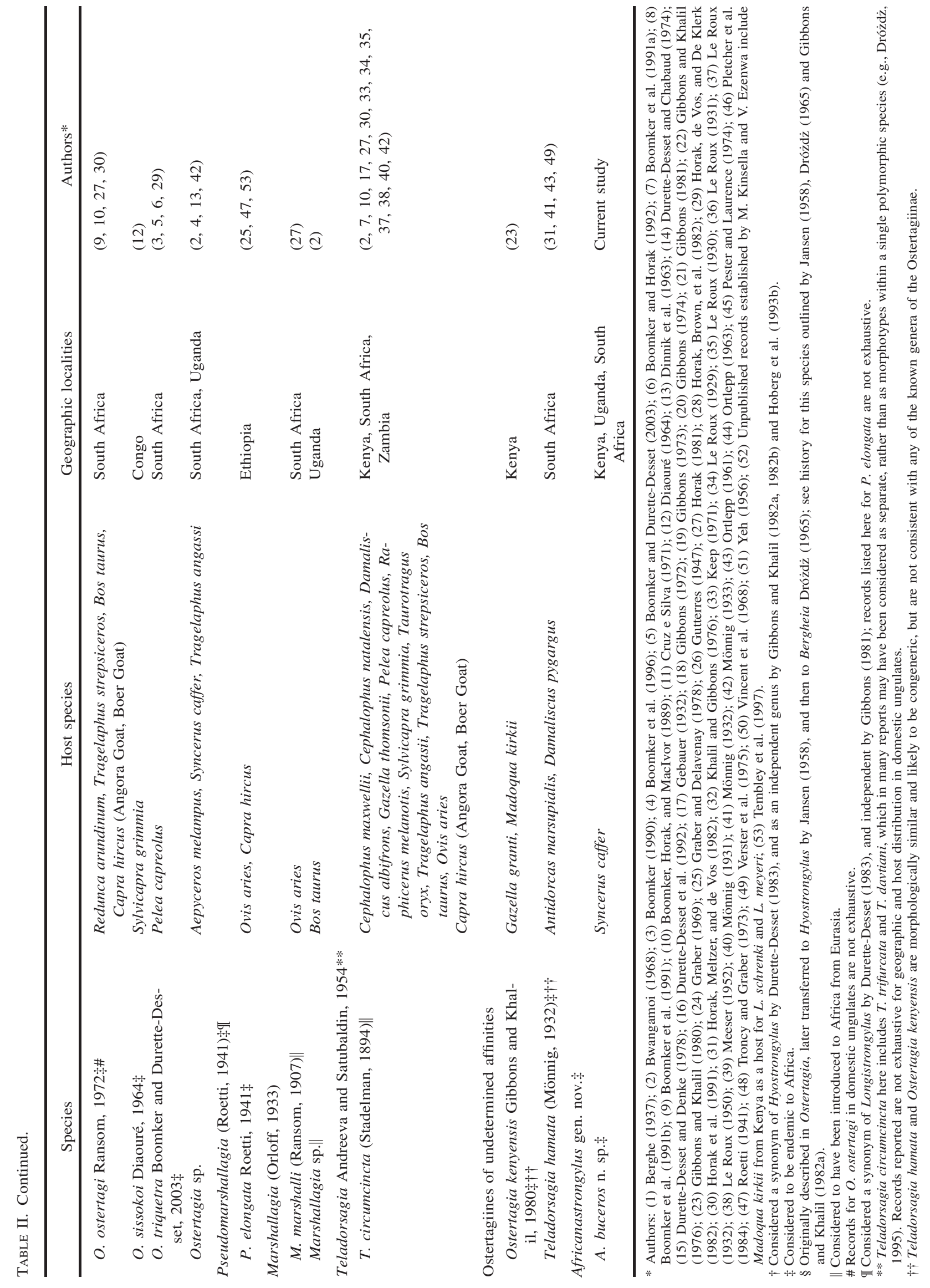


TABLE III. Morphometric comparisons for male specimens of Africanastrongylus buceros gen. nov. et sp. nov., Teladorsagia hamata and Ostertagia kenyensis.

\begin{tabular}{|c|c|c|c|}
\hline Characters & Africanastrongylus buceros & Teladorsagia hamata* & Ostertagia kenyensis $\dagger$ \\
\hline Number examined & 12 & - & 2 \\
\hline Body length & (10) $6,350-8,555(7,471 \pm 642.70)$ & $6,600-7,850$ & $9,740-12,110$ \\
\hline Esophagus length§ & (11) $688-825(757 \pm 49.65)$ & $710-800$ & $776-943$ \\
\hline Esophagus \% of body length & (10) $9.4-11.3(10.1 \pm 0.69)$ & $10.2-10.7$ & $7.8-8.0$ \\
\hline Esophageal-intestinal valve length & (10) 80-90 (91 \pm 5.48$)$ & 71 & 129 \\
\hline Esophageal-intestinal valve width & (10) $48-75(56 \pm 7.93)$ & 39 & 64 \\
\hline Nerve ring§ & (8) $250-335(303 \pm 25.61)$ & $240-290$ & - \\
\hline Subventral esophageal gland orifices§ & (10) $230-310(276 \pm 25.15)$ & - & - \\
\hline Excretory pore $\S$ & (10) 305-421 (370 \pm 31.16) & Near cervical papillae & $315-378$ \\
\hline Cervical papillae§ & (11) 330-445 (395 \pm 32.04$)$ & $330-420$ & $329-414$ \\
\hline Spicule length, left & (14) $195-246(212 \pm 14.08)$ & $161-191$ & $186-210$ \\
\hline Spicule, left, $\%$ trifurcation $\|$ & (13) 76-83 (79 \pm 2.2$)$ & 60 & 60 \\
\hline Spicule, length, right & (13) $190-240(207 \pm 15.19)$ & $161-191$ & $186-210$ \\
\hline Spicule, right, $\%$ trifurcation $\|$ & (12) 76-83 (79 \pm 2.6$)$ & $60-61$ & $60-62$ \\
\hline Gubernaculum length & (12) 60-82 (67 \pm 5.9$)$ & 112 & $95-129$ \\
\hline Gubernaculum width & (10) 35-42 (38 \pm 1.8$)$ & - & - \\
\hline
\end{tabular}

* Based on original description by Monnig (1932), and observations from a single male syntype.

$\dagger$ Based in part on original description by Gibbons and Khalil (1980), and examination of 2 male paratype specimens.

$\ddagger$ Numbers of individual specimens examined.

$\S$ Measured from anterior, cephalic extremity.

$\|$ Percentage from anterior to trifurcation of spicules.

ened. Additionally it appears that males of these species are monomorphic, although this requires confirmation through assessment of larger numbers of specimens in individual hosts.

Africanastrongylus buceros is distinguished, however, from $O$. kenyensis and T. hamata in the following manner: (1) tapering Type 1 synlophe (parallel Type 2 in $O$. kenyensis and T. hamata); (2) miniscule and thornlike cervical papillae; (3) midbody ridges numbering $>56$ in males and $>45$ in females (about 25-29 in O. kenyensis; about 35 in T. hamata); (4) presence of a proconus (absent in O. kenyensis and $T$. hamata); (5) membranous accessory bursal membrane containing divergent "7" papillae; (6) massive Rays 8 and Rays 9/10 (in $O$. kenyensis and T. hamata these rays have bases that are not inflated); (7)

TABLE IV. Morphometric comparisons for female specimens of Africanastrongylus buceros gen. nov. et sp. nov., Teladorsagia hamata and Ostertagia kenyensis.

\begin{tabular}{|c|c|c|c|}
\hline Number examined & 18 & - & 2 \\
\hline Body length & (18) $9,712-12,610(11,217 \pm 909.5)$ & $8,090-11,020$ & $13,230-15,120$ \\
\hline Esophagus $\%$ of body length & (18) $6.4-8.7(7.5 \pm 0.7)$ & $7.8-8.8$ & $6.7-7.0$ \\
\hline Esophageal-intestinal valve length & (17) $92-112(101 \pm 5.8)$ & - & 112 \\
\hline Esophageal-intestinal valve width & (17) $45-78(66 \pm 8.2)$ & - & 57 \\
\hline Excretory pore§ & (18) 305-482 (394 \pm 54.6$)$ & Near cervical papillae & $306-381$ \\
\hline Cervical papillae§ & (18) $320-545(421 \pm 63.5)$ & $320-420$ & $320-410$ \\
\hline Vulva position§ & (18) $8,075-10,275(9,239 \pm 648)$ & $6,750-9,260$ & $11,050-12,600$ \\
\hline Vulva \% body length & (18) $79-85(82 \pm 2.0)$ & $83-84$ & $83-84$ \\
\hline Ovejector total length\| & (10) $795-1,016(911 \pm 77.1)$ & - & $381-827$ \\
\hline Anterior infundibulum length & (11) $185-292(240 \pm 30.8)$ & - & $129-229$ \\
\hline Egg length & (90) $62-82(72 \pm 5.9)$ & 71 & $70-84$ \\
\hline Egg width & (90) $30-50(41 \pm 4.2)$ & 39 & $41-54$ \\
\hline Tail length & (15) $142-218(167 \pm 19.8)$ & $176-190$ & $143-219$ \\
\hline
\end{tabular}

* Based on original description by Mönnig (1932). Type or voucher specimens of females of this species were not available for examination.

$\dagger$ Based in part on original description by Gibbons and Khalil (1980), and examination of 2 paratype specimens.

$\star$ Numbers of individual specimens examined.

$\S$ Measured from anterior, cephalic extremity.

$\|$ Complete ovijector, combining infundibula, sphincters, and vestibule.

\# Combining Sphincter s1 and s2, consistent with Lichtenfels et al. (2003). 
absence of numerous fields of bursal bosses (numerous in $O$. kenyensis; absent in T. hamata); (8) the structure and dimensions of the alate gubernaculum with anteriorly directed horns (in T. hamata and O. kenyensis the gubernaculum is irregularly narrow); (9) structural differences in the spicule tips including the barbed and triangular ventral process and simple dorsal process of near equal length; (10) narrow, filamentous spicules; (11) substantially longer spicules; and (11) trifurcation of the spicule tips at $76-83 \%$ from the anterior $(60 \%$ in $O$. kenyensis and $T$. hamata) (Tables III, IV). Differences in the synlophe, genital cone, and bursal structure relative to A. buceros are those that separate genera. The generic placement of $T$. hamata and $O$. kenyensis remains undetermined, as neither species conforms to known ostertagiines with a 2 2-1 bursal pattern.

Africanastrongylus buceros is somewhat unusual among the ostertagiines in that males appear to have consistently greater numbers of ridges than females at all levels of the body. The only other report of this phenomenon of which we are aware is in Longistrongylus thalae (Troncy and Graber, 1973). In multiple specimens of L. thalae examined by Boomker and Durette-Desset (1997), there were 44-51 ridges in males and 42-45 in females at the level of the midbody. Males of $L$. thalae have a bursal formula of 2-1-2 and differ in other structural attributes relative to A. buceros (Troncy and Graber, 1973; Gibbons, 1981; Boomker and Durette-Desset, 1997).

\section{DISCUSSION}

\section{Dilemma of ostertagiine generic taxonomy}

Recognition of $A$. buceros gen. nov. et sp. nov. represents a dilemma for generic taxonomy among the ostertagiines, and highlights the continuing difficulty in establishing taxonomic limits and in defining unequivocal phylogenetic criteria for species groups within the subfamily. Although we have a reasonable understanding of phylogenetic criteria for the subfamily and hypotheses for a suite of synapomorphies that diagnose this larger taxon (Durette-Desset, 1983; Hoberg and Lichtenfels, 1994; Durette-Desset et al., 1999), the problematic nature of generic taxonomy remains. It appears accepted that differences in the $2-2-1$ and $2-1-2$ bursa, the configuration of lateral rays, dorsal lobe, and the structure of the synlophe, represent fundamental criteria in diagnosing genera and assemblages of genera within Ostertagiinae (e.g., Andreeva, 1956, 1958; Dróżdż, 1965; Durette-Desset and Chabaud, 1981; Gibbons and Khalil, 1982a; Durette-Desset, 1982, 1983, 1985, 1989; Jansen, 1989; Lichtenfels and Hoberg, 1993; Lichtenfels et al., 1993; Hoberg, 1996; Durette-Desset et al., 1999). It remains uncertain, however, when generic diagnoses should be emended to recognize the discovery of previously unknown diversity.

In establishing Africanastrongylus, we had 2 options: (1) extensively emend one or another of the existing genera to accommodate this species, or (2) recognize the apparent distinct nature of these nematodes relative to what we currently know about ostertagiine diversity. In the absence of a generic-level phylogeny, these alternatives each represent introduction of potential errors in a system where the goal should be to delineate monophyletic taxa or lineages as a basis for taxonomy. Thus, an incorrect inclusion of A. buceros among Longistrongylus or Sarwaria would confuse our potential interpretations of character evolution, biogeography, and host association if this species is actually not associated with either of these lineages. As a consequence, we consider our decision to recognize the distinct nature of $A$. buceros by establishing the new genus as conservative. As genetic, molecular, and morphological criteria increasingly become established with more extensive taxon sampling within this group, it will become possible to fully evaluate the hypothesis that Africanastrongylus represents. Concurrently, the problematic nature and incompatibility for the current taxonomy of $O$. kenyensis in Ostertagia and T. hamata in Teladorsagia remains apparent.

\section{Ostertagiines in African buffalo}

Wild African buffalo, or Cape buffalo, from the West Acholi District and the Queen Elizabeth National Park, Toro District, Uganda in the late 1960s, from Laikipia, Kenya in 2000, and from Hluhluwe-iMfolozi Park, South Africa in 2006, were infected with a previously undescribed species of ostertagiine nematode. We have established A. buceros for this unique abomasal nematode. There are relatively few reports of ostertagiine or trichostrongyloid nematodes as abomasal parasites in African buffalo (Table II), and these have been limited to $L$. meyeri and Ostertagia sp. from Uganda (Dinnik et al., 1963; Bwangamoi, 1968); A. lerouxi Diaouré, 1964 from Congo (Diaouré, 1964); H. bedfordi Le Roux, 1929 from Uganda (Dinnik et al., 1963) and South Africa (Le Roux, 1929; Ortlepp, 1961; V. O. Ezenwa, data not shown); H. contortus (Rudolphi, 1803) from Kenya and South Africa (Curson, 1928; Ezenwa, 2003); and H. placei Place, 1893 from Kenya (Ezenwa, 2003).

\section{Ostertagiine diversity in Africa}

Ostertagiines in the African fauna now include 25 species, representing 8 genera (Table II); among these, 21 species in 7 genera are apparently endemic to Africa, whereas 4 species in 4 genera have been introduced. Species diversity for Longistrongylus (8 species), Africanastrongylus (1), and Pseudomarshallagia (1) is restricted to Africa, with primary distributions among Antelopinae, Bovinae, Cephalophinae, and Hippotraginae. Although the latter genus has thus far only been reported in domestic caprines, species of Longistrongylus are also known as incidental parasites in sheep (Gibbons and Khalil, 1976). Endemic species from Africa are represented among Hyostrongylus (2) in gorillas and okapi (Berghe, 1937; Durette-Desset et al., 1992) and among Cervicaprastrongylus (2) in leporids and chevrotains (Durette-Desset and Chabaud, 1974; DuretteDesset and Denke, 1978), but additional diversity in these genera is distributed in Eurasia (Gibbons and Khalil, 1982b; Hoberg et al., 1993b). Durette-Desset $(1983,1989)$ reduces Bergheia Dróżdż, 1965 and Cervicaprastrongylus as synonyms of Hyostrongylus. The status of Hyostrongylus okapiae (Berghe, 1937), although retained here in Hyostrongylus, remains to be determined and will require additional and new specimens from okapi (Gibbons and Khalil, 1982b).

In Africa, Ostertagia constitutes a mosaic of endemic species (5, with exclusion of $O$. kenyensis) among Antelopinae, Bovinae, Cephalophinae, and Hippotraginae, and a single introduced species (Ostertagia ostertagi) found in domestic and wild ungulates. Additionally, Hyostrongylus rubidus, Marshallagia marshalli, and Teladorsagia circumcincta, including minor morphotypes for the latter, have been introduced and distributed in Africa coincidental with independent translocations and establishment of domestic swine, cattle, sheep, or goats (e.g., Daubney, 1933).

Placement for either $O$. kenyensis or $T$. hamata remains unresolved. Neither appears morphologically consistent with any known genus attributed to the Ostertagiinae. Among the group 
of 7 genera having a 2-2-1 bursa and either a tapering or a parallel lateral synlophe, a suite of structural characters would negate an unequivocal diagnosis for either species. Interestingly, specimens of both $T$. hamata and $O$. kenyensis are most similar to those attributed to minor morphotypes among the ostertagiines (e.g., Dróżdż, 1995) with robust spicules which trifurcate near $60 \%$ from the anterior, and a cuticularized and reduced accessory bursal membrane. Specimens of T. hamata have not been found in association with a putative major morphotype (Mönnig, 1932; Ortlepp, 1961; Verster et al., 1975; Horak et al., 1982), whereas $O$. kenyensis has not been reported since the original description (Gibbons and Khalil, 1980). A proposal to establish and diagnose another genus among the ostertagiines for $O$. kenyensis and $T$. hamata is deferred until such time as sufficient specimens become available for comparative studies.

Round (1968) includes a record for Camelostrongylus mentulatus (Railliet et Henry, 1909) in Gazella dama (Pallas), but this represents specimens collected from captive animals in a zoo; other records from Africa are lacking. Additionally, specimens referred to as Camelostrongylus harrisi (Le Roux, 1930) and Camelostrongylus sp. by Boomker et al. (1996) are correctly placed in Ostertagia. Camelostrongylus should be retained only for $C$. mentulatus, and confusion over the taxonomy of Ostertagia and Camelostrongylus emanates from nomenclatural decisions proposed by Durette-Desset (1989).

\section{Structure of the African ostertagiine fauna}

The African ostertagiine fauna is a complex mosaic reflecting historical processes across relatively deep to shallow temporal scales. Endemic faunas have origins associated with dispersal and biotic expansion from Eurasia into Africa and subsequent radiation for ungulates and their parasites extending from the late Tertiary. In Africa, structure of the fauna was likely to have been influenced by the differential timing of expansion events from Eurasia and periods of occupation for respective pecoran groups, including Antelopinae, Bovinae, Hippotraginae, Reduncinae, and others since the Miocene, in parallel to radiation among species of Haemonchus (Vrba 1985, 1995; Vrba and Schaller, 2000; Hoberg et al., 2004). Subsequently, domestication and later translocations during the Holocene for cattle and sheep (Ryder, 1984; Loftus et al., 1994) influenced distribution and diversity for trichostrongylid faunas (e.g., Daubney, 1933). Mosaic faunas among ungulate nematodes have now been demonstrated for all biogeographic regions (e.g., Hoberg et al., 1999, 2001, 2004; Hoberg, 2005).

Among 13 genera of the Ostertagiinae in the global fauna, 3 are entirely limited in distribution to Africa, including Africanastrongylus, Longistrongylus, and Pseudomarshallagia (Table II); the number would increase to 4 of 14 genera if a new taxon were established for T. hamata and $O$. kenyensis. Spiculopteragia among Cervidae and Camelostrongylus among antelopes and Caprinae, are the sole genera limited in distribution to Eurasia and the Palearctic; Sarwaria among Tragulidae and Bovinae appears limited to southern Asia. All other recognized genera are distributed in 2 or more biogeographic regions (discounting the influence of recent translocation). Among these, Cervicaprastrongylus among Tragulidae, Antelopinae, and Leporidae and Hyostrongylus among Suidae, Giraffidae, and Pon- gidae, are found in Asia and Africa, whereas Marshallagia, Mazamastrongylus, Orloffia, Ostertagia, and Teladorsagia among artiodactyls occur across the Holarctic. Among approximately 130-140 nominal species of ostertagiines, based in part on lists complied by Durette-Desset (1989) (discounting synonymies due to polymorphism among species of certain genera), 21 are limited to the African fauna. Thus, Africa is characterized by relatively few endemic species, but an apparently disproportionate number of endemic genera.

The diverse nature of the ostertagiine fauna may reflect the number and timing of episodic expansion events for artiodactyls into Africa from Eurasia during the Tertiary and Quaternary, their subsequent occupation times, and interactions with environmental variation over the past 3 million years (Hoberg and Brooks, 2008). Groups such as Orloffia, Ostertagia, Marshallagia, and Teladorsagia, or more generally trichostrongyloids among Cervidae and Caprinae (including the Nematodirinae), appear underrepresented or absent in the African fauna. Environmental tolerances established for such temperate and boreal adapted groups may have further limited expansion into African ecosystems (Hoberg et al., 2004; Hoberg, 2005).

Ostertagiines, other than species of Longistrongylus, contrast with Cooperiinae and Haemonchinae (Haemonchus and Ashworthius), as these latter taxa appear to have their greatest diversity centered in Africa, consistent with a history of radiation among artiodactyls (Gibbons, 1977, 1981; Durette-Desset, 1985; Hoberg et al., 2002, 2004). Cosmopolitan distributions for some species of Haemonchus and Cooperia were acquired subsequent to European exploration and a history of introductions from Africa after 1500 (Hoberg, 2005). Consequently, an understanding of the history and structure of parasite faunas in artiodactyls becomes increasingly important in defining the potential for translocation and establishment, geographic, and host colonization, and patterns of emergence for disease (Hoberg, 1997; Hoberg and Brooks, 2008). Baseline data are essential in formulating predictions about responses of complex host-parasite systems to ecological perturbation and climate change over time (Brooks and Hoberg, 2000; Hoberg et al., 2001; Hoberg, 2005; Brooks and Hoberg, 2006).

Biodiversity baselines are important in establishing a framework to document introductions and dissemination. Species of ostertagiines and haemonchines that could emanate from Africa as a source region have been recognized (Table II) (Hoberg et al., 2001). This concept was further validated by discovery of L. sabie in free ranging Hippotragus niger (Harris), Addax nasomaculatus (Blainville), and Oryx gazelle (Linnaeus), reported as Oryx biesa, from west Texas in a surrogate African ecosystem (Craig, 1993); Longistrongylus curvispiculum was also found in Oryx dammah (Cretzschmar), reported as Oryx tao, from England (Gibbons and Khalil, 1977). Africanastrongylus buceros may represent yet another species with the potential for successful translocation with infected ungulate hosts (Hoberg et al., 2001). Introduction and establishment of helminths with otherwise tropical histories and adaptations may have eventual consequences linked to the cascading effects of habitat change driven by global warming (Hoberg et al., 2004). Equally significant is the recognition that ecological disruption is a primary driver for geographic and host colonization, the emergence of novel associations of hosts, parasites, and pathogens, and for 
disease (Hoberg, 1997; Brooks and Hoberg, 2006; Hoberg and Brooks, 2008).

\section{ACKNOWLEDGMENTS}

We thank E. A. Harris of the Parasitic Worms Group, Department of Zoology, Natural History Museum, London, United Kingdom, for loan of specimens of $O$. kenyensis. We thank J. Boomker from the Department of Veterinary Tropical Diseases, University of Pretoria, South Africa, for access to African ostertagiines, including T. hamata. We thank M. Kinsella for referral of specimens that initiated the current study and for providing the image represented in Figure 35. We also thank P. Pilitt of the USNPC for reviews and comments on various drafts of this manuscript. Field collections for hosts and parasites by VOE in South Africa were funded by the National Science Foundation (DEB0541762) and by the Division of Biological Sciences, University of Montana.

\section{LITERATURE CITED}

ANDREEVA, N. K. 1956. Revizia ostertagieii (trikhostrongilid) zhvachnykh. Trudy Instituta Veterinarri, Kazakhskii Filiala Vsesoyuznoi. Sel'skokhozyaistvennykh Nauk 8: 473-487.

- 1958. Atlas of helminths (Strongylata) of domestic and wild ruminants of Kazakhstan. Institut Veterinarii Kazakhskogo Filiala VASHKhNIL, Tashkent.

Berghe, L. VAN DEN. 1937. Contribution à l'étude des parasites de l'Okapi. Revue de Zoologie et de Botanique Africaines 30: 117139.

BOOMKER, J. 1990. A comparative study of the helminth fauna of browsing antelope of South Africa. Ph.D. Dissertation. University of Southern Africa, Pretoria, South Africa, 297 p.

-, D. G. Booyse, R. Watermeyer, I. L. DE Villiers, I. G. HoraK, AND J.R.B. Flamand. 1996. Parasites of South African wildlife. XIV. Helminths of nyalas (Tragelaphus angasii) in the Mkuzi Game Reserve, KwaZulu-Natal. Onderstepoort Journal of Veterinary 63: 265-271.

- AND M.C. DuRETte-Desset. 1997. Supplement to the description of Longistrongylus thalae (Troncy \& Graber, 1973) Gibbons, 1981 (Nematoda: Ostertagiinae). Systematic Parasitology 36: 6973.

, AND - 2003. Parasites of South African wildlife. XVII Ostertagia triquetra $\mathrm{n}$. sp. (Nematoda: Trichostrongylina) from the grey rhebuck, Pelea capreolus (Forster, 1790). Onderstepoort Journal of Veterinary Research 70: 37-41.

- AND I. G. HoraK. 1992. Parasites of South African wildlife. XIII. Helminths of grey rhebuck, Pelea capreolus, and bontebok, Damaliscus dorcas dorcas, in the Bontebok National Park. Onderstepoort Journal of Veterinary Research 59: 175-182.

- - AND J.R.B. Flamand. 1991a. Parasites of South African wildlife. X. Helminths of red duikers, Cephalophus natalensis, in Natal. Onderstepoort Journal of Veterinary Research 58: 205-209.

life,, XII. Helm $1991 \mathrm{~b}$. Parasites of South African wildderstepoort Journal of Veterinary Research 58: 275-280.

, AND M. M. KNIGHT. 1991. Parasites of South African wildlife. IX. Helminths of kudu, Tragelaphus strepsiceros, in the eastern Cape Province. Onderstepoort Journal of Veterinary Research 58: 203-204.

$\longrightarrow,-$ AND K. M. MACIVOR. 1989. Helminth parasites of grysbok, common duikers, and Angora and Boer goats in the Valley Bushveld in eastern Cape Province. Onderstepoort Journal of Veterinary Research 56: 165-172.

Brooks, D. R., AND E. P. Hoberg. 2000. Triage for the biosphere: The need and rationale for taxonomic inventories and phylogenetic studies of parasites. Comparative Parasitology 68: 1-25.

$\longrightarrow$, AND $\longrightarrow$. 2006. Systematics and emerging infectious diseases: From management to solution. Journal of Parasitology 92: 426-429.

BWANGAMOI, O. 1968. Helminth parasites of domestic and wild animals in Uganda. Bulletin of Epizootic Diseases of Africa 16: 429-454.

Chabaud, A. G. 1977. Spiculopteragia caballeroi sp. nov. nematode
Trichostrongylidae parasite de Tragulus javanicus. In Excreta parasitològica en memoria del Doctor Eduardo Caballero y Caballero. Universidad Nacional Autònome de México, Mexico City, D.F., p. 415-418.

, F. Puylaert, O. Bain, A. J. Petter, and M. C. Durette-DesSET. 1970. Remarques sur l'homologie entre les papilles cloacales des Rhabdites et les côtes dorsales des Strongylida. Comptes Rendus Hebdomadaire des Séances de l'Academie des Sciences, Paris 271: $1771-1774$.

CRAIG, T. M. 1993. Longistrongylus curvispiculum (Nematoda: Trichostrongyloidea) in free-ranging exotic antelope in Texas. Journal of Wildlife Diseases 29: 516-517.

CruZ E Silva, J.A. 1971. Contribuição para o estudo dos helmintes parasites dos vertebrados de Moçambique. Memórias da Junta de Investigaçoes do Ultrmar No. 61, 479 p.

CuRson, H. H. 1928. Metazoan parasites from Zululand. South African Journal of Natural History 6: 181-187.

Daubney, R. 1933. Trichostrongylid nematodes from sheep in Kenya. Parasitology 25: 224-241.

Diaouré, A. 1964. Strongylides parasites de mammiféres du CongoBrazzaville. Annales de Parasitologie Humaine et Comparée 39: 243-284.

DinNik, J. A., J. B. Walker, S. F. BARnetT, AND D. W. Brocklesby. 1963. Some parasites obtained from game animals in western Uganda. Bulletin of Epizootic Diseases of Africa. 11: 37-44.

DRóżDŻ, J. 1965. Studies on helminths and helminthiasis in Cervidae. I. Revision of the subfamily Ostertagiinae Sarwar, 1956 and an attempt to explain the phylogenesis of its representatives. Acta Parasitologica Polonica 13: 455-481.

. 1995. Polymorphism in the Ostertagiinae Lopez-Neyra, 1947 and comments on the systematics of these nematodes. Systematic Parasitology 32: 91-99.

Durette-Desset, M. C. 1982. Sur les divisions génériques des Nématodes Ostertagiinae. Annales de Parasitologie Humaine et Comparée 57: $375-381$

1983. Keys to the genera of the superfamily Trichostrongyloidea, Vol. 10. In $\mathrm{CIH}$ keys to the nematode parasites of vertebrates, R. C. Anderson and A. G. Chabaud (eds.). Commonwealth Agricultural Bureaux, Farnham Royal, U.K., 86 p.

. 1985. Trichostrongyloid nematodes and their vertebrate hosts: Reconstruction of the phylogeny of a parasitic group. Advances in Parasitology 24: 239-306.

- 1989. Nomenclature proposee pour les especes decrites dans la sous-famille des Ostertagiinae Lopez-Neyra, 1947. Annales de Parasitologie Humaine et Comparée 64: 356-373.

- AND A. G. Chabaud. 1974. Trois nouveaux nématodes parasites du chevrotain aquatique: Hyemoschus aquaticus au Gabon (collection G. Dubost). Bulletin du Museum National d'Histoire Naturelle 105: $75-87$.

, AND —. 1981. Nouvel essai de classification des Nématodes Trichostrongyloidea. Annales Parasitologie Humaine et Comparée 56: 297-312.

, R. W. AshFord, T. Butynski, AND G.D.F. ReID. 1992 Two new species of the Trichstrongylidae (Nematoda: Trichostrongyloidea), parasitic in Gorilla gorilla beringei in Uganda. Systematic Parasitology 23: 159-166.

-, AND M. DENKE. 1978. Description de Nématodes parasites d'un Lièvre africain et compléments à l'étude morphologique de quelques Trichostrongylidae. Bulletin du Museum National d'Histoire Naturelle, Paris $3^{\mathrm{e}}$ série, $\mathrm{n}^{\mathrm{o}} 515$ Zoologie 354: 331-347.

, J. P. Hugot, P. Darlu, AND A. G. Chabaud. 1999. A cladistic analysis of the Trichostrongyloidea (Nematoda). International Journal for Parasitology 29: 1065-1086.

EzENwA, V.O. 2003. Habitat overlap and gastrointestinal parasitism in sympatric African bovids. Parasitology 126: 379-388.

Gebauer, O. 1932. Zur kenntnis der Parasitenfauna der Gemse. Zietschrift für Parasitenkunde 4: 147-220.

GibBons, L. M. 1972. Kobusinema banagiense sp. nov. a new Trichostrongylid Nematode from African game animals. Journal of Helminthology 46: 213-218.

- 1973. Bigalkenema curvispiculum sp. nov. (Nematoda: Trichostrongylidae) from East African game animals, with a redescription 
of Kobusinema banagiense Gibbons, 1972. Journal of Helminthology 47: 303-310.

1974. Recent records of nematodes in East African mammals. Helminthological Abstracts Series A 43: 641-646.

. 1977. Revision of the genera Longistrongylus Le Roux 1931. Kobusinema Ortlepp, 1963 and Bigalkenema Ortlepp, 1963 (Nematoda: Trichostrongylidae). Journal of Helminthology 51: 41-62. - 1981. The taxonomic position of the nematode species Pseudomarshallagia thalae (Troncy and Graber, 1973) Graber and Delavenay, 1978 (Family Trichostrongylidae). Systematic Parasitology 2: 217-218.

, AND L. F. KHALIL. 1976. Bigalkenema curvispiculum, Longistrongylus meyeri and Haemonchus spp. (Neamtoda: Trichostrongylidae) in sheep and goats in Kenya. Tropical Animal Health Production 8: 168 .

, AND - 1977. Longistrongylus curvispiculum (Gibbons, 1973) (Nematoda: Trichostrongyloidea) in Oryx tao in England. Journal of Helminthology 51: 209-210.

, AND - 1980. Some new trichostrongylid nematodes from East African artiodactylids. Systematic Parasitology 1: 91-104. , AND —. 1982a. A key for the identification of genera of the nematode family Trichostrongylidae Leiper, 1912. Journal of Helminthology 56: 185-233.

$\longrightarrow$, AND 1 1982b. Cervicaprastrongylus, a new genus proposed for the nematode species Ostertagia skrjabini Singh \& Pande, 1963 (Trichostrongyloidea, Trichostrongylidae). Systematic Parasitology 4: 93-98.

Graber, M. 1969. Helminthes parasites de certains animaux domestiques et sauvages du Tchad. Bulletin of Epizootic Diseases of Africa 17: 403-428.

- And R. Delavenay. 1978. Pseudomarshallagia elongate Roetti, 1941 (Nematoda: Trichostrongyllidae), parasite de la caillette des petits ruminants d'Ethiopia. Revue d'Èlevage et de Médecine Vétérinaire des Pays Tropicaux 31: 353-359.

GutTERES, J. DE B. 1947. Contribuição para o estudo dàs verminoses gastrointestinais dos bovinos africanos, A. tricoestrongilinose bovina em Africa. Ph.D. Dissertation. University of Lisbon, Lisbon, Portugal, 92 pp.

HoberG, E. P. 1996. Emended description of Mazamastrongylus peruvianus (Nematoda: Trichostrongylidae), with comments on the relationships of the genera Mazamastrongylus and Spiculopteragia. Journal of Parasitology 82: 47-477.

- 1997. Parasite biodiversity and emerging pathogens: A role for systematics in limiting impacts on genetic resources. In Global genetic resources: Access, ownership and intellectual property rights, K.E. Hoagland and A.Y. Rossman (eds.). Association of Systematics Collections, Washington, D.C., p. 71-83.

. 2005. Coevolution and biogeography among Nematodirinae (Nematoda: Trichostrongylina) Lagomorpha and Artiodactyla (Mammalia): Exploring determinants of history and structure for the Northern fauna across the Holarctic. Journal of Parasitology 91: $358-369$.

, AND A. ABrams. 2007. Emended description and redetermination of Sarwaria caballeroi n. comb. (Nematoda: Ostertagiinae) with details of the synlophe and esophageal characters. Journal of Parasitology 93: 1140-1150.

, - R. A. Carreno, And J. R. Lichtenfels. 2002. Ashworthius patriciapilittae $\mathrm{n}$. sp. (Trichostrongyloidea: Haemonchinae), an abomasal nematode in Odocoileus virginianus from Costa Rica, and a new record for species of the genus in the Western Hemisphere. Journal of Parasitology 88: 1187-1199.

— AND D. R. BRooKs. 2008. A macroevolutionary mosaic: Episodic host switching, geographic colonization and diversification in complex host-parasite systems. Journal of Biogoegraphy. (In press).

-, AND A. V. Khrustalev. 1996. Re-evaluation of Mazamastrongylus dagestanica (Trichostrongylidae) with descriptions of the synlophe, genital cone, and other structural characters. Journal of Parasitology 82: 778-787.

- A. A. KoCAN, AND L. G. RICKARD. 2001. Gastrointestinal strongyles in wild ruminants. In Parasitic diseases of wild mammals, W. Samuel, M. Pybus and A.A. Kocan (eds.). Iowa State University Press, Ames, Iowa, p. 193-227.
, AND J. R. LiChTENFELs. 1994. Phylogenetic systematic analysis of the Trichostrongylidae (Nematoda), with an initial assessment of coevolution and biogeography. Journal of Parasitology 80: 976996.

, - AND L. GibBons. 2004. Phylogeny for species of Haemonchus (Nematoda: Trichostrongyloidea): Considerations of their evolutionary history and global biogeography among Camelidae and Pecora (Artiodactyla). Journal of Parasitology 90: 1085-1102. , AND P. A. PILITT. 1993a. Synlophe of Cooperia neitzi (Trichostrongylidae: Cooperiinae) with comments on vulval inflations and hypertrophy of cuticular ridges among the trichostrongylids. Journal of the Helminthological Society of Washington 60: $153-161$.

1993b. Affiliation of Hyostrongylus rubidus (Nematoda: Trichostrongylidae) with the Ostertagiinae, and evaluation of the synlophe and other structural characters. Journal of the Helminthological Society of Washington 60: 219-233.

, K. J. Monsen, S. KutZ, And M. S. Blouin. 1999. Structure, biodiversity, and historical biogeography of nematode faunas in Holarctic ruminants: Morphological and molecular diagnoses for Teladorsagia boreoarcticus $\mathrm{n}$. sp. (Nematoda: Ostertagiinae) a dimorphic cryptic species in muskoxen. Journal of Parasitology 85: 910-934.

HorAK, I. G. 1981. Host specificity and the distribution of the helminth parasites of sheep, cattle, impala and blesbok according to climate. Journal of the South African Veterinary Medical Association 52: 201-206.

, M. R. Brown, J. Boomker, V. De Vos, And E. A. VAn Zyl. 1982. Helminth and arthropod parasites of blesbok, Damaliscus dorcas phillipsi and of bontebok, Damaliscus dorcas dorcas. Onderstepoort Journal of Veterinary Research 49: 139-146.

- V. DE Vos, AND B. D. DE KLERK. 1982. Helminth and arthropod parasites of vaal ribbok, Pelea capreolus, in the western Cape Province. Onderstepoort Journal of Veterinary Research 49: 147-148.

-, M. M. KNIGHT, AND E. J. Williams. 1991. Parasites of domestic and wild animals in South Africa. XXVIII. Helminth and arthropod parasites of Angora goats and kids in Valley Bushveld. Onderstepoort Journal of Veterinary Research 58: 253-260.

, D.G.A. Meltzer, AND V. DE Vos. 1982. Helminth and arthropod parasites of springbok, Antidorcas marsupialis, in the Transvaal and western Cape Province. Onderstepoort Journal of Veterinary Research 49: 7-10.

JANSEN, J. 1958. Lebmaagtrichostrongyliden bij nederlanse herten. H.J. Smits. Utrecht, The Netherlands, $100 \mathrm{p}$.

. 1989. A concise history of the Ostertagiinae Lopez-Neyra, 1947 (Nematoda: Trichostrongylidae) and a discussion on its composition. Acta Leidensia 58: 151-159.

KeEP, M. E. 1971. Some parasites and pathology of the nyala, Tragelaphus angasii and its potential value as a ranch animal. Lammergeyer 13: $45-54$.

KhaLIL, L. F., AND L. M. GibBons. 1976. The helminth parasites of suni, Nesotragus moschatus von Dueben, 1846 from Kenya with the description of a new genus and two new species of nematodes (Vermes). Revue Zoologie Africa 90: 559-577.

LE RouX, P. L. 1929. A preliminary report on three new members of the genus Haemonchus Cobb, 1898, from antelopes in South Africa. 15th Annual Report of the Director of Veterinary Services, Department of Agriculture, Union of South Africa, p. 481-491.

1930. On two Helminths from the abomasum of the bushbuck in Zululand, Natal. 16th Annual Report of the Director of Veterinary Services and Animal Industry, Union of South Africa, p. 233241.

. 1931. On Longistrongylus meyeri gen. and sp. nov., a trichostrongyle parasitizing the Red Hartebeest Bubalis caama. Journal of Helminthology 9: 141-146.

1932. List of helminths collected from mammals and birds in the Mazabuku area, Northern Rhodesia. Annual Report, 1931, Department of Animal Health, Northern Rhodesia. Appendix B, pp. 31-34.

. 1950. Trichostrongylus leiperi sp. nov., a parasite of the leand (Taurotragus oryx) in Northern Rhodesia. Journal of Helminthology 24: $28-32$.

Lichtenfels, J. R., AND E. P. Hoberg. 1993. The systematics of nem- 
atodes that cause ostertagiasis in domestic and wild ruminants in North America: An update and key to species. Veterinary Parasitology 46: 33-53.

, P. A. PilitT, AND A.G.M. Belem. 1993. A comparison of cuticular ridge patterns and other morphological characters of Mazamastrongylus odocoilei and Mazamastrongylus pursglovei (Nematoda: Trichostrongyloidea) from the white-tailed deer Odocoileus virginianus. Systematic Parasitology 24: 1-15.

- AND T. M. CRAIG. 1996. The synlophe and other structural characteristics of Sawaria bubalis (Nematoda: Trichostrongyloidea) from cattle in Guyana. Journal of Parasitology 82: $146-154$.

, P. A. PilitT, AND L. M. GibBons. 2003. Ovejector structure in the Haemonchinae (nematode: Trichostrongyloidea) of ruminants. Journal of Parasitology 89: 984-993.

, AND M. B. LANCASTER. 1988. Cuticular ridge patterns of seven species of Ostertagiinae (Nematoda) parasitic in domestic ruminants. Proceedings of the Helminthological Society of Washington 55: 77-86.

Loftus, R. T, D. E. MacHugh, D. G. Bradley, and P. M. Sharp. 1994 Evidence for two independent domestications of cattle. Proceedings of the National Academy of Sciences USA 91: 2757-2761.

MeESER, M.J.N. 1952. A preliminary survey of the ecto and endoparasites of the impala-Aepyceros melampus. Journal of the South African Veterinary Medical Association 23: 221-223.

MöNNIG, H. O. 1931. Wild antelopes as carriers of nematode parasites of domestic ruminants-Part I. 17th Report of the Director of Veterinary Services and Animal Industry, Union of South Africa, p. 233-254.

. 1932. Wild antelopes as carriers of nematode parasites of domestic ruminants-Part II. 18th Annual Report of the Director of Veterinary Services and Animal Industry, Union of South Africa, p. $153-172$.

. 1933. Wild antelopes as carriers of nematode parasites of domestic ruminants-Part III. Onderstepoort Journal of Veterinary Science and Animal Industry 1: 77-92.

ORTLEPP, R. J. 1961. Noorsig van Suid-Afrikaanse helminte veral met verwysing na die wat in ons wildherkouers voorkom. Tydskrif vir Natuurwetenskappe, Pretoria 1: 203-212.

- 1963. Bigalkenema namaquensis gen. and sp. nov. a trichostrongylid worm from sheep. Onderstepport Journal of Veterinary Research, South Africa 30: 119-124.

Pester, F. R. N., and B. R. Laurence. 1974. The parasite load of some African game animals. Journal of Zoology, London 174: 397-406.
Pletcher, J. M., I. G. Horak, V. De Vos, AND J. Boomker. 1984. Nodular abomasitis in impala (Aepyceros melampus) caused by the nematode Longistrongylus sabie. Journal of Parasitology 70: 907910.

RoetTi, C. 1941. Un elminta del genre Ostertagia parassita degli ovini e caprini-nuova specie. Annali di Patalogia Tropicale e Parassitologia 2: 251-256.

Round, M. C. 1968. Check list of the helminth parasites of African mammals. Technical Communication No. 38. Commonwealth Agricultural Bureaux, Franham Royal, Bucks, U.K., 252 p.

RYDER, M. L. 1984. Sheep. In Evolution of domesticated animals, I. L. Mason (ed.). Longman, New York, New York, p. 63-85.

Tembley, S., A. Lahlou-Kassi, J. E. Rege, S. Sovani, M. L. Diedhiou, AND R. L. BAKER. 1997. The epidemiology of nematode infections in sheep in a cool tropical environment. Veterinary Parasitology 70: $129-141$

Travassos, L. P. 1937. Revisão da familia Trichostrongylidae Leiper, 1912. Institute Oswaldo Cruz Monographs 1: 1-512.

Troncy, P. M., AND M. GRABER. 1973. Ostertagia thalae n. sp., parasite d'antilopes d'Afrique Centrale. Revue d'Elevage et de Medicine Veterinaire de Pays Tropicaux. 26: 221-224.

Verster, A., G. D. ImeS, AND J.P.J. Smit. 1975. Helminths recovered from the bontebok. Damaliscus dorcas dorcas (Pallas, 1766). Onderstepoort Journal of Veterinary Research 42: 29-32.

Vincent, R., P. M. Hitchins, R. C. Bigalke, and A. J. Bass. 1968. Studies on a population of nyala. Lammergeyer 33: 1-89.

VRBA, E. S. 1985. African Bovidae: Evolutionary events since the Miocene. South African Journal of Science 81: 263-266. . 1995. The fossil record of African antelopes (Mammalia: Bovidae) in relation to human evolution and paleoclimate. In Paleoclimate and evolution with emphasis on human origins, E. S. Vrba, G. S. Denton, T. C. Partridge, and L. H. Burkle (eds.). Yale University Press, New Haven, Connecticut, p. 385-424.

, AND G. B. Schaller. 2000. Phylogeny of the Bovidae based on behavior, glands, skulls, and postcrania. In Antelopes, deer and relatives: Fossil record, behavioral ecology, systematics and conservation, E. S. Vrba and G. B. Schaller (eds.). Yale University Press, New Haven, Connecticut, p. 203-202.

Wilson, D. E., AND D. M. ReEDER. 1993. Mammals species of the world. A taxonomic and geographic reference. Smithsonian Institution Press, Washington, D.C., 1207 p.

YEH, L. S. 1956. On a collection of helminths from Thomson's gazelle, Gazella thomsoni, from Tanganyika. Journal of Helminthology 29: 203-228. 